\title{
THE DOCTRINAL UNITY OF ALTERNATIVE LIABILITY AND MARKET-SHARE LIABILITY
}

\author{
MARK A. GEISTFELD ${ }^{\dagger}$
}

Market-share liability has been one of the most controversial doctrines in tort law, with a strong plurality of courts rejecting the doctrine on the ground that it radically departs from the fundamental tort principle of causation. Courts that have adopted this liability rule, though, believe they are adhering to the principle of causation. In the first case to adopt market-share liability, the California Supreme Court claimed that the liability rule is grounded upon an extension of alternative liability, a doctrine that has been accepted by virtually all jurisdictions. The court never adequately explained how alternative liability can be modified to yield market-share liability, and the only explanation provided by torts scholars involves redefining the tort right to permit compensation for tortious risk, conditional upon the occurrence of injury, rather than for the injury itself. However, courts do not conceptualize the tort right in these terms, for otherwise the doctrine of market-share liability would be uncontroversial. As this Article shows, marketshare liability can be derived from alternative liability in a manner that neither redefines the tort right nor departs from the principle of causation. Alternative liability permits the plaintiff to prove causation against the group of defendants. This characterization of the causal rule has been recognized by some torts scholars, but has never been justified. The Article shows that evidential grouping is a defensible principle implicit in numerous cases involving analogous causal problems, including the asbestos cases. Evidential grouping not only explains the doctrine of alternative liability, it shows how a modification of that liability rule yields market-share liability largely for reasons given by the California Supreme Court. This conceptualization of alternative liability and market-share liability also explains the otherwise puzzling liability rule adopted by courts in the asbestos

\footnotetext{
${ }^{\dagger}$ Crystal Eastman Professor of Law, New York University School of Law. I am grateful for the extremely helpful comments I received from Jules Coleman, David Fischer, Michael Green, Anthony Seebok, Catherine Sharkey, Alex Stein, Benjamin Zipursky, and participants in the faculty workshop at NYU Law School. This article more rigorously develops an argument I previously made in MARK A. GEISTFELD, PRINCIPLES OF PRODUCTS LIABILITY 167-79 (2006). Support for both projects was provided by The Filomen D'Agostino and Max E. Greenberg Research Fund of the New York University School of Law.
} 
cases. Due to this doctrinal unity, the widespread acceptance of alternative liability should make market-share liability more widely acceptable.

INTRODUCTION .448

I. Alternative Liability AND Evidential GROUPING

A. The Puzzle of Alternative Liability .454

B. Evidential Grouping in a Principled Manner.

C. Evidential Grouping as the Basis for Alternative Liability....

II. MARKET-SHARE LIABILITY AND EVIDENTIAL GROUPING 477

III. FURTHER IMPLICATIONS OF EVIDENTIAL GROUPING 485

A. Simultaneity 486

B. Number of Defendants

C. Proximity. 488

D. Apportionment of Liability and the Joinder Requirement

E. Proof of Risk Contribution

F. The Plaintiff's Causal Responsibility

CONCLUSION .499

\section{INTRODUCTION}

The doctrine of market-share liability may have deep implications for tort law. The reason involves the element of causation. To establish tort liability, the plaintiff must prove by a preponderance of the evidence that the defendant's tortious conduct caused the injury for which she seeks compensation. ${ }^{1}$ The element of causation ties the violation of the plaintiff's tort right to the defendant's breach of duty, entitling the plaintiff to receive compensation from the defendant wrongdoer. A difficult causal question arises when a plaintiff can sufficiently prove that multiple manufacturers acted tortiously by selling defective fungible products, each of which may have caused the plaintiff physical harm and one of which did, but the plaintiff cannot identify the particular manufacturer that sold the injury-causing product. In the seminal case Sindell v. Abbott Laboratories, the California Supreme Court held that the plaintiff could recover against such a group of manufacturers comprising a "substantial share" of the relevant market. $^{2}$ As the court subsequently made clear, this doctrine of marketshare liability imposes several liability upon each defendant manufac-

\footnotetext{
${ }^{1}$ E.g., Smith v. Eli Lilly \& Co., 560 N.E.2d 324, 328 (Ill. 1990) (describing the causal requirement as "[a] fundamental principle of tort law").

2607 P.2d 924, 937 (Cal. 1980).
} 
turer in proportion to its market share. ${ }^{3}$ A manufacturer that had ten percent of the relevant market, for example, would be severally liable for ten percent of the plaintiff's harm. According to the preponderance of the evidence, this manufacturer did not cause the plaintiff's harm; the evidence only establishes that the manufacturer created a ten percent chance of causing the injury. The defendant manufacturer may thus be incurring liability only for the tortious imposition of risk, with the profound implication that the plaintiff's tort right involves protection from risk rather than protection from physical harm.

Market-share liability is commonly understood in precisely this fashion. In a series of influential articles, leading torts scholars have argued that market-share liability is based upon an emergent riskbased conception of tort liability that is formulated to promote deterrence in a fair manner. ${ }^{4}$ A deterrence-based torts system devises liability rules in order to reduce unreasonable risks. That objective does not depend upon the occurrence of physical harm, because an actor who faces liability for creating an unreasonable risk has an incentive to act reasonably. ${ }^{5}$ But when the liability rule instead requires that the unreasonable risk must actually cause physical harm, the actor can avoid liability in conflict with the deterrence objective. The unrea-

\footnotetext{
${ }^{3}$ Brown v. Superior Court, 751 P.2d 470, 486-87 (Cal. 1988).

${ }^{4}$ See, e.g., Glen O. Robinson, Multiple Causation in Tort Law: Reflections on the DES Cases, 68 VA. L. REv. 713, 749 (1982) (concluding that Sindell "point[s] toward a rule that imposes liability for the creation of a risk and apportions liability according to the magnitude of that risk"); David Rosenberg, The Causal Connection in Mass Exposure Cases: A "Public Law" Vision of the Tort System, 97 HARV. L. REv. 849, 866-68 (1984) (identifying market-share liability as a form of proportional liability based upon the risk that the defendant caused injury); Richard W. Wright, Causation in Tort Law, 73 CAL. L. REV. 1735, 1819-20 (1985) ("In effect, the Sindell court recognized a new legal injury: tortious exposure to a risk that possibly led to a subsequent injury."); see also Joseph H. King, Jr., Causation, Valuation, and Chance in Personal Injury Torts Involving Preexisting Conditions and Future Consequences, 90 YALE L.J. 1353, 1381 (1981) (arguing that the Sindell decision "is an important signal of the increased willingness of courts to integrate chance into its resolution of torts cases"). Although the analyses in each of these articles proceed from quite different premises about the appropriate purpose of tort liability, their shared perspectives illustrate the wide-ranging agreement among torts scholars about the appropriate interpretation of market-share liability.

${ }^{5}$ Cf. William M. Landes \& Richard A. Posner, The Economic Structure of TORT LAW 229 (1987) (explaining why "the idea of causation can largely be dispensed with in an economic analysis of torts" that seeks to reduce risks in order to minimize accident costs); Guido Calabresi, Concerning Cause and the Law of Torts: An Essay for Harry Kalven, Jr., 43 U. CHI. L. REv. 69, 85 (1975) ("One could do away with the but for test and employ other methods to [decide whether avoidance is worthwhile]. For example, one could simply guess at the size of the injury costs that will be associated in the future with behavior causally linked to such injury costs.").
} 
sonable risk may not materialize into injury. The unreasonable risk may not double the underlying risk of injury, making it impossible for the plaintiff to prove that the physical harm, more likely than not, was caused by the tortious conduct rather than by the underlying risk of injury. Or the plaintiff may only be able to identify the group of actors who created the tortious risk but not the particular actor who caused the physical harm, as in the market-share cases. These safety problems could be avoided if the plaintiff can establish liability by proving that the defendant exposed her to an unreasonable risk of physical harm. This form of liability is also fair insofar as the moral quality of a defendant's behavior does not depend upon the fortuity, or "moral luck," of whether the unreasonable risk caused physical harm. Rather than distinguish among otherwise identical actors on the contingent basis of whether their unreasonable behavior caused physical harm, tort liability could treat each actor equally by making each responsible for her own behavior-the unreasonable risk she imposed upon the plaintiff. ${ }^{6}$

A pure risk-based liability rule has two substantial practical problems that are avoided by market-share liability. First, once liability no longer depends upon the occurrence of physical harm, there will be a huge increase in the number of suits. Second, plaintiffs who were exposed to the same risk will receive the same damages, regardless of whether they actually suffer the physical harm. To reduce the number of lawsuits and increase the amount of compensation available to the physically injured victims, a risk-based tort rule can be conditional upon the occurrence of physical harm. Only those individuals who were exposed to the risk and suffered the type of physical harm threatened by the risk can recover. If the underlying risk were 1 in 10,000 , for example, the harm requirement ordinarily would yield 1 claim for every 10,000 individuals exposed to the risk, whereas a rule lacking that requirement would produce up to 10,000 claims. The reduced number of claimants also increases the amount of compensation for the physically harmed victims. For example, an injured plain-

\footnotetext{
${ }^{6}$ See Jeremy Waldron, Moments of Carelessness and Massive Loss, in PHILOSOPHICAL FOUNDATIONS OF TORT LAW 387, 401-05 (David G. Owen ed., 1995) (explaining why the "liability lottery" based on the occurrence of physical harm can be fair, but no more so than other liability schemes like those based on the creation of risk); Christopher H. Schroeder, Corrective Justice and Liability for Increasing Risks, 37 UCLA L. REV. 439, 462-66 (1990) (using the theory of corrective justice to argue that an individual should be liable for increasing the risk of harm, whether or not the harm actually occurs).
} 
tiff could sue a single manufacturer having ten percent of the market and recover damages for ten percent of the total harm. Even though the plaintiff was exposed to a small risk of injury (1 in 10,000), given that she has been physically harmed, the likelihood is ten percent that this particular manufacturer caused the harm. By conditioning liability on the occurrence of physical harm, market-share liability can reduce the number of suits, increase the amount of compensation for physically harmed victims, and still compensate the plaintiff for risk exposure and not for the injury itself-the evidence only establishes the risk exposure, conditional upon the occurrence of physical harm, and does not prove that the ten percent risk actually caused the injury.

Despite the appeal of market-share liability, the doctrine has had a mixed reception in the courts. The prototypical case for market-share liability involves the synthetic drug diethylstilbestrol (DES). A "number of courts" have adopted market-share liability in these cases, but a "roughly equal number of courts have declined to craft a new theory for DES plaintiffs, expressing concern that to do so would rend too great a chasm in the tort-law requirement of factual causation."

As this case law reveals, the courts do not conceptualize marketshare liability as providing compensation for exposure to a tortious risk. A DES plaintiff typically can prove that each defendant DES manufacturer, more likely than not, exposed her to a tortious risk that may have caused the physical harm. By establishing that a defendant manufacturer had ten percent of the relevant market, for example, the plaintiff has proven that this defendant exposed her to a ten percent chance of causing the physical harm. The causal requirement would be satisfied, then, if the tort compensation were for the risk exposure, conditional upon the occurrence of the physical harm, rather than for the harm itself. Courts, however, have concluded that market-share liability would "rend too great a chasm," implying that the liability must be based upon the tortious infliction of physical harm. The fact that a defendant DES manufacturer had ten percent of the relevant market does not prove that its product, more likely than not, caused the plaintiff's bodily injury. The tort right must protect individuals from physical harm in order for so many courts to conclude that market-share liability "requires a profound change in fundamen-

${ }^{7}$ Restatement (Third) OF TORTS: Liab. FOR Physical Harm $\$ 28 \mathrm{cmt}$. o (Proposed Final Draft No. 1, 2005) (collecting cases showing that no more than twenty jurisdictions have decided the issue, with nine rejecting market-share liability). 
tal tort principles of causation .... [W] e cannot pretend that any such theory is consistent with common law principles of tort liability."

The courts that have actually adopted market-share liability, though, do not believe that it departs from the fundamental tort principle of causation. In the first case to adopt market-share liability, the California Supreme Court said that the liability rule is "grounded upon an extension of the Summers doctrine." The court was referring to the rule of alternative liability adopted in the famous case of Summers v. Tice. ${ }^{10}$ Today, "most courts appear to regard [Summers] as established law on its facts." ${ }^{11}$ Insofar as market-share liability is merely an extension of Summers, the doctrine does not depend upon divergent opinions about the principle of causation or the substantive content of the tort right as involving protection from physical harm (and not merely risk exposure).

Rather than representing conflicting views about the tort principle of causation, the sharply divided case law on market-share liability most plausibly stems from a disagreement about whether the Summers doctrine properly extends to market-share liability. Although the California Supreme Court sought to justify market-share liability in these terms, it never clearly explained the relevance of the Summers doctrine for market-share liability. ${ }^{12}$ Nor has it adequately explained the Summers doctrine of alternative liability. ${ }^{13}$ Torts scholarship has not sufficiently clarified matters either. In rejecting both alternative liability and market-share liability, one court observed that "none of the cases or commentaries presents a rigorous analysis of why [the doctrines are] 'fair.", ${ }^{4}$ The courts that have rejected market-share liability are understandably wary of the claim that it can be justified by alternative liability.

\footnotetext{
${ }^{8}$ Senn v. Merrell-Dow Pharms., Inc., 751 P.2d 215, 223 (Or. 1988); see also Smith v. Eli Lilly \& Co., 560 N.E.2d 324, 334-40 (Ill. 1990) (providing a survey of cases rejecting market-share liability and stressing the common theme that the liability rule is a "radical" departure from tort principles).

${ }^{9}$ Sindell v. Abbott Labs., 607 P.2d 924, 928 (Cal. 1980).

${ }^{10} 199$ P.2d 1 (Cal. 1948).

11 DAN B. DOBBS, THE LAW OF TORTS $§ 175$, at 428 (2000).

${ }^{12}$ See Zafft v. Eli Lilly \& Co., 676 S.W.2d 241, 246 (Mo. 1984) (en banc) (rejecting market-share liability in part because Sindell had not sufficiently articulated the relevant concepts).

${ }^{13}$ E.g., DOBBS, supra note 11, $\$ 175$, at 427 ("The opinion in Summers did not spell out the reasons for this extraordinary liability in any precise way ....").

${ }^{14}$ Senn v. Merrell-Dow Pharms., Inc., 751 P.2d 215, 222 (Or. 1988).
} 
Part I accordingly begins with the Summers doctrine of alternative liability, explaining why the rationale for this doctrine does not have to depend upon a novel theory of compensation for risk exposure. To recover, the plaintiff must satisfy the ordinary burden of proving causation with respect to the group of defendant tortfeasors. Others have conceptualized alternative liability in this manner, but have not explained why the plaintiff can defensibly group a number of independent tortfeasors in order to establish causation. ${ }^{15}$ Part I identifies a principle implicit in cases involving an analogous causal problem and then shows how this principle can justify grouping the defendants for evidentiary purposes. Part I concludes by showing how evidential grouping persuasively yields the rule of alternative liability.

Part II then explains why this rationale for alternative liability extends to market-share liability, requiring a change in the liability rule to reflect the different circumstances in the two types of cases. Evidential grouping enables the plaintiff to prove causation against the group of defendant DES manufacturers, although the underlying principle of fairness limits the extent of a defendant's liability to the extent of its responsibility for the causal group. That limitation is provided by each defendant's share of the relevant market. Evidential grouping unites both alternative liability and market-share liability, and so the widespread acceptance of alternative liability should help to make market-share liability more widely acceptable.

Part III concludes by identifying some implications of evidential grouping. Market-share liability does not have to be limited to DES cases or even to those matters involving defective products. When the requirements for evidential grouping are satisfied, liability is based upon the tortious risk created by each defendant, a factor not necessarily dependent on market shares. The liability rule accordingly provides many of the benefits of risk-based liability that have been lauded by torts scholars. The justification for liability, however, is based upon established tort principles, not on a profound change in the nature of the individual right protected by tort law.

${ }^{15}$ See infra notes 30-33 and accompanying text. 


\section{Alternative LiabiLity AND EVIDENTIAL GROUPING}

\section{A. The Puzzle of Alternative Liability}

In the leading case of alternative liability, Summers $v$. Tice, ${ }^{16}$ the plaintiff was injured while hunting quail with the two defendants. Each defendant negligently fired his shotgun in the direction of the plaintiff at about the same time from approximately the same distance. The plaintiff was struck in the eye and face by a single shot of pellets, but could not identify which defendant's shot had hit him. The evidence only established that each defendant had an equal likelihood of doing so, leaving the plaintiff unable to prove that either defendant, more likely than not, caused the injury. Nevertheless, the California Supreme Court concluded that it was appropriate to shift the burden of proof to the defendants, requiring each to prove that he was not the cause of the plaintiff's injury. If neither defendant could provide such proof, each would be jointly liable for the plaintiff's injury.

This rule of alternative liability has been adopted by the Restatement (Second) of Torts:

Where the conduct of two or more actors is tortious, and it is proved that harm has been caused to the plaintiff by only one of them, but there is uncertainty as to which one has caused it, the burden is upon each such actor to prove that he has not caused the harm. ${ }^{17}$

The rationale for alternative liability is based upon "the injustice of permitting proved wrongdoers, who among them have inflicted an injury upon the entirely innocent plaintiff, to escape liability merely because the nature of their conduct and the resulting harm has made it difficult or impossible to prove which of them has caused the harm." ${ }^{18}$ This justification tracks the reasoning of the Summers court. ${ }^{19}$

The rule has gained widespread acceptance as reflected in its adoption by the Restatement (Third) of Torts. ${ }^{20}$ According to the Restate-

16199 P.2d 1 (Cal. 1948).

${ }^{17}$ Restatement (SECOND) OF TORTS $§ 433 B(3)$ (1965).

${ }^{18} I d$. cmt. f.

19 See Summers, 199 P.2d at 2-4 (identifying other cases involving similar facts resulting in liability and concluding that liability does not depend upon a concert of action among the defendants, as courts had previously found, but instead upon the injustice of allowing the defendants to avoid liability despite the plaintiff's proof that one of them tortiously caused the harm).

${ }^{20}$ The Restatement (Third) states: 
ment (Third), the "rationale for shifting the burden of proof to defendants whose tortious conduct exposed the plaintiff to a risk of harm is that, as between two culpable defendants and an innocent plaintiff, it is preferable to put the risk of error on the culpable defendants." ${ }^{21}$

As formulated, the Restatement rationales for alternative liability are not fully persuasive. The Restatement rule of alternative liability expressly applies to "two or more actors," and so the liability rule clearly contemplates that the defendants would incur liability if Summers had involved three defendant shooters instead of two. A case of this type requires further explanation as to why the plaintiff has proven the prima facie case of liability against each of the three defendants. The plaintiff's proof only shows that each defendant created a one-third chance of causing the injury, a substantial departure from the ordinary evidentiary rule requiring the plaintiff to prove that each defendant, more likely than not, caused the harm. The Restatement rationales never explain why the plaintiff's proof makes each defendant "culpable" in a manner that justifies shifting the burden of proof.

For this same reason, the Restatement rationales do not adequately identify the reasons for disabling each defendant from avoiding liability by relying upon this infirmity in the plaintiff's prima facie case. But, once the liability rule shifts the burden of proof to the three defendants in a modified Summers case, each one could prove, by a preponderance of the evidence, that he did not cause the plaintiff's harm; more likely than not, the remaining group of two defendants caused the harm. That type of exculpatory causal proof would completely undermine the rule of alternative liability in any case involving three or more tortfeasors. After proving that the injury was tortiously caused by an unidentifiable tortfeasor within the group of defendants, the plaintiff would be unable to recover if each of the three or more defendants could then disprove causation by relying on the morelikely-than-not evidentiary standard as applied to the remaining group of defendants. The final result would produce the "injustice" that the

When the plaintiff sues all of multiple actors and proves that each engaged in tortious conduct that exposed the plaintiff to a risk of physical harm and that the tortious conduct of one or more of them caused the plaintiff's harm but the plaintiff cannot reasonably be expected to prove which actor caused the harm, the burden of proof, including both production and persuasion, on factual causation is shifted to the defendants.

Restatement (Third) OF TORTS: Liab. FOR Physical HARM $§ 28$ (b) (Proposed Final Draft No. 1, 2005).

${ }^{21} I d$. cmt. f (citing RESTATEMENT (SECOND) OF TORTS $§ 433 \mathrm{~B}(3) \mathrm{cmt}$. f (1965)). 
rule of alternative liability is designed to avoid. The "proved wrongdoers, who among them have inflicted an injury upon the entirely innocent plaintiff [would] escape liability merely because the nature of their conduct and the resulting harm has made it difficult or impossible to prove which of them has caused the harm." ${ }^{22}$ To avoid this injustice, the liability rule must be interpreted so that a defendant cannot admit that he may have tortiously caused the harm and then exculpate himself solely on the ground that the factual uncertainty implies that the remaining defendants, more likely than not, caused the injury. The Restatement (Third) limits a defendant's exculpatory causal proof in this manner without explanation or justification. ${ }^{23}$

The Restatement (Second) presumably bars such causal proof due to the "injustice" of allowing the defendant wrongdoers to escape liability only because their tortious conduct created factual uncertainty about the actual cause of the injury. But tortious conduct routinely creates factual uncertainty regarding causation. A defendant who exposed a physically injured plaintiff to a ten percent risk of harm may have been the actual cause of the injury, but our limited knowledge of the relevant causal processes only allows the causal statement to take a probabilistic form. In such a case, the mere fact that the defendant's tortious conduct makes it impossible for the plaintiff to prove causation by a preponderance of the evidence does not ordinarily relieve the plaintiff of the burden of proof, nor does the factual uncertainty disable the defendant from disproving causation by relying on the more-likely-than-not evidentiary standard. What explains the different rule with respect to alternative liability?

The Restatement (Third) does not sufficiently clarify matters by simply concluding that as between the "culpable" defendant and "innocent" plaintiff, the "risk of error" should be put on the defendant. ${ }^{24}$ Carried to its logical conclusion, this proposition implies that a single defendant who has acted tortiously should have to disprove causation with certainty, for that rule places the risk of error (liability in cases

${ }^{22}$ Restatement (SECOND) OF TORTS $§ 433 B(3) \mathrm{cmt}$. f (1965).

${ }^{23}$ The Restatement (Third) states:

Defendants would be able to satisfy their burden of production when three or more defendants are subject to alternative liability in one of two ways: a defendant might show why it was not the cause of plaintiff's injury or it might show which one of the other defendants was the cause.

RESTATEMENT (THIRD) OF TORTS: LIAB. FOR PHYSICAL HARM $\$ 28$ reporters' note $\mathrm{cmt}$. j (Proposed Final Draft No. 1, 2005). Why the defendant's exculpatory proof is limited to these two forms of proof is never explained or justified.

${ }^{24} I d . \S 28(\mathrm{~b}) \mathrm{cmt}$. f. 
lacking complete certainty) on the culpable defendant rather than the innocent plaintiff. This possibility is acknowledged and summarily rejected by the Restatement (Third): "The justification for alternative liability might logically begin with consideration of the singledefendant case in which plaintiff can prove tortious conduct but is unable to prove factual causation. Yet courts do not ordinarily shift the burden of proof in those cases." ${ }^{25}$ By not shifting the burden of proof in these cases, courts have rejected the proposition that the "risk of error" should always be placed upon a defendant who has acted unreasonably rather than upon the "innocent" plaintiff. What makes that proposition valid in cases of alternative liability?

In contrast to the Restatement rationales for alternative liability, the doctrine is easy to understand when liability is based upon the tortious infliction of risk. The plaintiff in Summers proved, by a preponderance of the evidence, that each defendant tortiously created a fifty percent risk of causing the harm in question. Neither defendant could provide causal proof to the contrary. Each defendant incurred liability for fifty percent of the plaintiff's total damages, an amount exactly corresponding to the probability that he caused the harm. The plaintiff received full compensation for the injury from the two defendants, but the liability of each defendant was based upon risk and not the tortious infliction of injury. The risk-based interpretation of alternative liability has been adopted by numerous torts scholars. ${ }^{26}$

This rationale for alternative liability is problematic. It implies that the widespread acceptance of alternative liability should make market-share liability widely acceptable. However, by rejecting market-share liability, a strong plurality of courts have shown that they are not willing to make a defendant liable for merely exposing the plaintiff to a tortious risk of causing the harm. ${ }^{27}$ The widespread judicial acceptance of alternative liability must rest upon some other rationale, which would explain why the Restatements do not justify the doctrine as a means of compensating the plaintiff for exposure to tortious risk.

The doctrine of alternative liability could instead be interpreted as relaxing the causation requirement, so that the plaintiff need not prove, by a preponderance of the evidence, that a defendant tortiously caused the physical harm. Under this interpretation, the plaintiff can sufficiently prove that the defendant actually caused the harm

\footnotetext{
${ }^{25} I d$.

${ }^{26}$ This interpretation is adopted by all of the sources cited in note 4, supra.

${ }^{27}$ See supra notes 7-8 and accompanying text.
} 
by proving that the defendant may have caused the harm. The tort compensation is for the injury, and the liability rule merely reduces the plaintiff's burden of proving causation.

This interpretation is also hard to square with the case law, since a strong plurality of courts have rejected the identical rationale for market-share liability. These courts are unwilling to adopt marketshare liability if doing so "would rend too great a chasm in the tort-law requirement of factual causation." ${ }^{28}$ The unwillingness of these courts to adopt a doctrine that erodes the causal requirement strongly suggests that they did not adopt alternative liability in order to ease the plaintiff's burden of proving causation.

In light of the case law, alternative liability most plausibly involves compensation for physical harm without relaxing the plaintiff's burden of proving causation. To operate in this manner, alternative liability must apply the plaintiff's causal proof to the group of defendants rather than to each defendant individually. In Summers, for example, the plaintiff proved that the two defendants, considered together, more likely than not caused the physical harm. As the Summers court concluded, "we believe it is clear that the [trial] court sufficiently found on the issue that defendants were jointly liable and that thus the negligence of both was the cause of the injury or to that legal effect." ${ }^{29}$ By applying the plaintiff's causal proof to the group of defendants, alternative liability does not reduce the plaintiff's burden of proving causation with respect to the tortious infliction of physical harm.

According to a leading torts treatise, the doctrine of alternative liability can be expressed in terms of such a causal rule:

When the conduct of two or more actors is so related to an event that their combined conduct, viewed as a whole, is a but-for cause of the event, and application of the but-for rule to them individually would absolve all of them, the conduct of each is a cause in fact of the event. ${ }^{30}$

${ }^{28}$ Restatement (Third) OF TORTS: Liab. FOR Physical Harm $\$ 28 \mathrm{cmt}$ o (Proposed Final Draft No. 1, 2005).

${ }^{29}$ Summers v. Tice, 199 P.2d 1, 2 (Cal. 1948).

${ }^{30}$ W. Page Keeton et al., Prosser and Keeton on the Law of Torts $\S 41$, at 268 (5th ed. 1984). 
A similar causal rule has been proposed by a few scholars. ${ }^{31}$ It has never been adequately developed, however. As another leading treatise observes:

[I]t depends on a decision to group various acts of various defendants together, and on a decision about what acts should be treated in this collective manner. At least to some extent, the decision to aggregate conduct of different defendants, and the decision to include or exclude specific acts in that aggregate unit, is likely to be a policy decision, or merely an intuitive selection. In either case, it may generate further legal issues, this time over the criteria for the policy decisions.

Lacking any identifiable principle that justifies grouping the conduct of independent actors for causal purposes, this solution to the evidentiary problem has been summarily rejected by leading causal theorists. ${ }^{33}$ Only one court has expressly adopted evidential grouping, and it did so without fully understanding the underlying principle. ${ }^{34}$

31 See J.L. Mackie, The Cement of the Universe: A Study of Causation 265-66 (1974) (noting the distinction between two "kinds of cause: producing causes and explanatory causes"); Charles E. Carpenter, Concurrent Causation, 83 U. PA. L. REv. 941, 944-45 (1935) (proposing "a rule as to proof in the concurrent cause cases" where "proof of cause both in fact and law is relaxed" by allowing the plaintiff to establish these elements, in part, with evidence showing that her "injury did happen from one of the several or the collective operation of such independent causes, of which the defendant's was one"). For the most extensive treatment of the grouping approach (dubbed "collective liability"), see ARIEL PORAT \& ALEX STEIN, TORT LIABILITY UNDER UNCERTAINTY 130-59 (2001). Porat and Stein conclude that collective liability can be justified by considerations of corrective justice and deterrence under certain conditions. They do not otherwise identify the tort principle that would justify grouping the defendants for evidentiary purposes, but instead assume that there is a "well-identified group" of actors. Id. at 131-32.

${ }^{32}$ DoBBS, supra note $11, \S 171$, at 417.

3 E.g., Michael D. Green, The Intersection of Factual Causation and Damages, 55 DePAUl L. REV. 671, 682 (2006) ("[T] here is a certain, arbitrary quality to this rationale that is troubling. But for the torts of one of the hunters [in Summers] and another hunter on the other side of the county who fired carelessly and hit nothing, the victim would not have suffered harm."); Wright, supra note 4, at 1780-81 (rejecting the Prosser and Keeton causal rule because it "cannot distinguish duplicative causes from preempted conditions" and "would treat totally unrelated conditions as causes").

${ }^{34}$ See Spaur v. Owens-Corning Fiberglas Corp., 510 N.W.2d 854, 858 (Iowa 1994) (agreeing with the causal rule articulated by Prosser and Keeton). The Iowa Supreme Court had previously rejected market-share liability, partly for the reason that any modification of the causation requirement is a legislative decision. See Mulcahy v. Eli Lilly \& Co., 386 N.W.2d 67, 75 (Iowa 1986) (rejecting "market share liability theory on a broad policy basis"). Market-share liability, however, can be justified by evidential grouping for reasons given in Part II, infra. The Spaur court's adoption of evidential grouping, therefore, is inconsistent with the Mulcahy court's prior rejection of marketshare liability, indicating that the Iowa Supreme Court did not understand fully the principle underlying evidential grouping. 
Nevertheless, solving the causal problem by grouping the defendants has obvious appeal. It is the only rationale capable of explaining how alternative liability does not relax the plaintiff's burden of proving causation or otherwise provide compensation for the tortious exposure to risk. Others have solved the causal problem in this manner, and their failure to specify its underlying rationale does not mean it lacks one. To understand adequately the rule of alternative liability, we need to determine whether there is a principle that justifies grouping a number of independent tortfeasors for the purpose of establishing causation.

\section{B. Evidential Grouping in a Principled Manner}

When one tortfeasor is responsible for the conduct of another, tort law groups the two together for liability purposes. A coconspirator is liable for the tortious injuries caused by other coconspirators in furtherance of the conspiracy. ${ }^{35}$ One who aids and abets a tortfeasor is liable for the resultant injuries. ${ }^{36}$ An employer is vicariously liable for the torts committed by an employee within the scope of her employment. ${ }^{37}$ In each type of case, one tortfeasor incurs joint and several liability for an injury that was caused by another tortfeasor's conduct. The two have acted as a group in causing the plaintiff's injury, either in terms of the tortious conduct itself, as in cases of conspiracy or aiding and abetting, or in terms of a preexisting relationship, as in cases of vicarious liability. By joining the group, each defendant tortfeasor becomes responsible for the tortious injuries proximately caused by the group, regardless of whether the defendant directly caused the harm.

In contrast to liability grouping, tort law can rely upon less demanding forms of grouping for evidentiary purposes. Unlike liability grouping, evidential grouping does not make a defendant responsible for the conduct of other tortfeasors, because there is nothing about any defendant's conduct that warrants such responsibility. One of the defendant shooters in Summers is simply not responsible for the conduct of the other defendant shooter; otherwise the case would involve a concert of action governed by liability grouping. The plaintiff could

\footnotetext{
${ }^{35}$ RESTATEMENT (SECOND) OF TORTS $\$ 876$ (1977) (describing when one is subject to liability for "harm resulting to a third person from the tortious conduct of another").

${ }^{36} I d$.

${ }^{37}$ DoBBs, supra note $11, \S 333$, at 905.
} 
get full recovery from a single shooter as a member of the group, regardless of whether that shooter actually shot the plaintiff. But, even if each defendant is not responsible for the conduct of the other defendants, it may still be justifiable to group their conduct for evidentiary purposes. The evidential grouping only supports the plaintiff's prima facie case of liability, without making each defendant responsible or liable for the tortious conduct of the other defendants.

To be justifiable, evidential grouping must redress an injustice that would otherwise be created by the ordinary evidentiary rule requiring proof of but-for causation with respect to each individual defendant. A rule of this type would not treat defendants unfairly, for reasons given by Arthur Ripstein and Benjamin Zipursky:

Any procedure is at best an imperfect way of realizing ... justice in a world of uncertainty. As a result, procedural rules may work an injustice in a particular case. If they do, the party who would stand to benefit from that injustice cannot complain that he is being wronged if a court acts to prevent it. For neither party to a lawsuit has the right to procedures that favour him; at most each party has a right to procedures that are not unfair. ${ }^{38}$

To evaluate evidential grouping in these terms, we need to consider more closely the problem addressed by alternative liability. In these cases, the plaintiff was tortiously harmed by one of the defendants, but the available evidence does not enable the plaintiff to identify the actual tortfeasor. The limited evidence creates an intractable problem of factual uncertainty.

Tort law allocates factual uncertainty to the parties according to the burden of proof. Ordinarily, the plaintiff must prove each element of a tort, including causation, by a preponderance of the evidence, often called the more-likely-than-not evidentiary standard. ${ }^{39}$ This standard allows for the possibility that some nonculpable or innocent defendants will incur liability. It also allows for the possibility that some deserving plaintiffs will not be compensated. For example, suppose the plaintiff establishes all elements other than causation. If the evidence conclusively shows there is a $50.1 \%$ chance that the de-

\footnotetext{
${ }^{38}$ Arthur Ripstein \& Benjamin C. Zipursky, Corrective Justice in an Age of Mass Torts, in Philosophy And the Law of ToRTs 214, 235 (Gerald J. Postema ed., 2001). Ripstein and Zipursky are expressly discussing corrective justice in this passage, but the point generalizes.

${ }^{39}$ See, e.g., Ronald J. Allen \& Sarah A. Jehl, Burdens of Persuasion in Civil Cases: Algorithms v. Explanations, 2003 MICH. ST. L. REV. 893, 897-904 (explaining why the burden of proof applies to each element individually rather than to the entire tort claim).
} 
fendant caused the harm, the plaintiff can recover, despite a $49.9 \%$ chance that the defendant did not cause the harm. Conversely, if the evidence conclusively shows that there is a $50.1 \%$ chance that the defendant did not cause the harm, the plaintiff cannot recover, despite a $49.9 \%$ chance that the defendant did cause the harm. That is, the ordinary evidentiary standard expressly allows for a $49.9 \%$ chance that a defendant who did not actually cause the harm will be liable (a "false positive") and a $49.9 \%$ chance that a defendant who did in fact cause the harm will avoid liability (a "false negative").

By giving equal treatment to false positives and false negatives, tort law has adopted a norm that gives equal weight or concern to (1) the interest of a nonculpable defendant in avoiding liability judgments based on limited factual information (a false positive), and (2) the interest of a deserving plaintiff who cannot establish her right to compensation only because of limited factual information (a false negative). The tort norm, in other words, strives to apportion equally the burden of factual uncertainty or erroneous legal determinations between a nonculpable defendant and a deserving plaintiff. ${ }^{40}$

So understood, the tort norm governing the fair allocation of factual uncertainty neither requires nor forecloses proof applied to defendants individually or as a group. Consider the relevant interests at stake in the modified Summers case involving three identically situated defendant shooters. When the causal evidence applies to the group of defendants, the plaintiff can prove that he was harmed by their tortious conduct and is a deserving plaintiff. As a factual matter, the plaintiff's interest is appropriately characterized in this manner. The evidence shows that the plaintiff was tortiously harmed and deserves compensation. The only factual uncertainty involves the identity of the actual tortfeasor, creating the hard question of whether the uncertainty prevents the otherwise deserving plaintiff from recovering against any individual defendant. The factual uncertainty must be allocated so that the interest of the deserving plaintiff is given the same weight as the interest of a nonculpable defendant, but this norm does not determine how the interests of the parties should be characterized. Just as the nature of the plaintiff's interest can be determined by the way in which the evidence applies to the group of defendants, the interest of each defendant can be similarly determined. The issue in-

\footnotetext{
${ }^{40}$ See, e.g., PORAT \& STEIN, supra note 31, at 18, 37-42 (discussing the allocation of risk of error to promote equality and corrective justice in tort law).
} 
volves a distinctive normative judgment - the one addressed by a principle that justifies evidential grouping.

This principle can be extracted from cases involving multiple tortfeasors, each of whose conduct was sufficient to cause the harm in question. The classic example involves two independent tortfeasors who negligently started separate fires that subsequently merged and destroyed the plaintiff's property. ${ }^{41}$ Each fire was sufficient to cause the entirety of the plaintiff's damage, and so the plaintiff cannot prove that either fire was a but-for cause of the injury. If this form of causal proof were inadequate, the plaintiff would be denied recovery altogether, despite having proven that the injury was tortiously caused by the two defendants. In these cases, "all courts impose liability on both tortfeasors without requiring 'but for' causation [as applied to each defendant individually]. Courts do this to avoid the obvious injustice of allowing each culpable tortfeasor to escape liability to an innocent victim by hiding behind the negligence of the other tortfeasor." ${ }^{42}$

In a set of analogous cases, one defendant tortiously caused the plaintiff's harm, and then another defendant's tortious conduct subsequently duplicated part of that harm in an unrelated accident. A leading example involves an initial tortfeasor permanently disabling the plaintiff's leg in an automobile accident, and a second tortfeasor shooting the plaintiff in the leg a few years later, necessitating amputation of the leg. ${ }^{43}$ The second tortfeasor cannot be liable for the duplicated harm (permanent disability of the leg), because one cannot cause an injury that has already occurred. ${ }^{44}$ Only the first tortfeasor could be liable for the duplicated harm, but she can argue that the

${ }^{41}$ E.g., Anderson v. Minneapolis St. Paul \& Sault Ste. Marie Ry. Co., 179 N.W. 45, 48 (Minn. 1920), overruled in part on other grounds by Borsheim v. Great N. Ry. Co., 183 N.W. 519, 521 (Minn. 1921) (upholding the lower court's instruction that if the fires combined to burn plaintiff's property, the defendant is liable).

${ }^{42}$ David A. Fischer, Successive Causes and the Enigma of Duplicated Harm, 66 TENN. L. REV. 1127, 1129-30 (1999) (citations omitted); see also Jane Stapleton, Legal Cause: Cause-in-Fact and the Scope of Liability for Consequences, 54 VAND. L. REV. 941, 966-68 (2001) (arguing that the choice to impose the requirement of but-for causation in cases of overdetermined harm is a normative one).

${ }^{43}$ See Baker v. Willoughby, (1970) 2 W.L.R. 50, 58 (H.L.) (appeal taken from Eng. C.A.) (arguing that in such an accident, "[i]f the supervening event is a tort, the second tortfeasor should be responsible for the additional devaluation caused by him") (Pearson, L., concurring).

${ }^{44}$ See Restatement (Third) OF TORTs: Liab. FOR Physical Harm $\$ 27 \mathrm{cmt}$. h (Proposed Final Draft No. 1, 2005) ("Once the harm has occurred, any other cause that remains incomplete is not a cause of harm."). 
harm (permanent disability), more likely than not, would have occurred anyway due to the other tortfeasor's ensuing negligent conduct (requiring amputation). This form of exculpatory proof has been rejected by the courts. "Generally, courts hold the first tortfeasor liable for all the harm caused by the first accident, including the duplicated harm." ${ }^{45}$ As in the two-fire cases, this rule avoids the injustice of enabling all defendants to avoid liability due to the negligence of other defendants when the plaintiff's proof shows that she was tortiously injured by at least one of the defendants. ${ }^{46}$

The same principle applies to cases involving toxic substances and diseases. As the Maryland Court of Appeals explained:

In products liability involving asbestos, where the plaintiff has sufficiently demonstrated both lung disease resulting from exposure to asbestos and that the exposure was to the asbestos products of many different, but identified, suppliers, no supplier enjoys a causation defense solely on the ground that the plaintiff would probably have suffered the same disease from inhaling fibers originating from the products of other suppliers. ${ }^{47}$

A defendant manufacturer cannot avoid liability merely because the injury, more likely than not, was caused by the defective products sold by the other defendants. This rule is adopted by the Restatement (Third) for all cases involving toxic substances and diseases. ${ }^{48}$

All of these cases involve evidential grouping. In each one, the plaintiff has proven, by a preponderance of the evidence, that she was

\footnotetext{
${ }^{45}$ Fischer, supra note 42 , at 1155 . "Although there is very little consideration of this situation in American case law, cases from Britain and Canada are in agreement." Green, supra note 33 , at 30 .

${ }^{46}$ In the duplicated-harm cases, the second tortfeasor avoids liability due to the negligence of the first tortfeasor, but there is an important difference between the two parties. The first actor's tortious conduct is a necessary element in a set of sufficient causal conditions that were operating at the time of that conduct, making it a factual cause of the harm. See RESTATEMENT (THIRD) OF TORTS: LIAB. FOR PHysical Harm $\S$ $27 \mathrm{cmt}$. f (Proposed Final Draft No. 1, 2005) (“[T] he fact that the other person's conduct is sufficient to cause the harm does not prevent the actor's conduct from being a factual cause of the harm ...."). Once the injury has already occurred, the second tortfeasor's conduct is never necessary for the occurrence of injury, thus eliminating it as a cause of the harm. Id. $\$ 26 \mathrm{cmt}$. k ("An act or omission cannot be a factual cause of an outcome that has already occurred."). The requirement of causation accordingly absolves the second tortfeasor from liability, while enabling the plaintiff to receive full recovery for the duplicated harm from the first tortfeasor.

${ }^{47}$ Eagle-Picher Indus., Inc. v. Balbos, 604 A.2d 445, 459 (Md. 1992).

48 See Restatement (Third) OF TORTs: Liab. FOR Physical Harm $\S 27 \mathrm{cmt}$. g (Proposed Final Draft No. 1, 2005) (“[S] ome of the person's exposure may not have been a but-for cause of the disease. Nevertheless, each of the exposures . . . is a factual cause of the person's disease ....").
} 
injured by tortious conduct engaged in by the defendants, and that each defendant's tortious conduct may have actually caused or contributed to the injury. Due to the circumstances of the case, the ordinary evidentiary rule requiring proof of individualized, but-for causation would absolve each defendant from liability, even though the plaintiff has proven that each defendant may have caused the harm and at least one of them did. To avoid this outcome, the courts allow the plaintiff to prove causation against the group of defendant tortfeasors, and then bar each defendant from relying on exculpatory evidence showing that the injury, more likely than not, was caused by the tortious conduct of the other defendants, when that proof, as applied to each individual defendant, would deny recovery to the deserving plaintiff. Once this exculpatory evidence is ruled out, a defendant can avoid liability only by showing that she either did not act tortiously or could not possibly have caused the harm. This type of exculpatory proof excludes the defendant from the otherwise indistinguishable group of defendants that tortiously caused the harm. Lacking such proof, each defendant shares liability for the plaintiff's harm.

To be sure, not all of these cases involve factual uncertainty, and many of them can be explained by a test that deems a particular factor to have caused an injury if it is a necessary element in a set of existing conditions that was independently sufficient to cause the harm. The so-called NESS (Necessary Element of a Sufficient Set) test, for example, identifies each of the two negligent fires as a tortious cause: "Each fire was necessary for the sufficiency of a set of existing antecedent conditions that contained it but not the other fire." ${ }^{49}$ As this description suggests, the NESS test is hardly intuitive or easy to apply, particularly when compared to evidential grouping. ${ }^{50}$

More fundamentally, the NESS test cannot adequately explain some cases that involve evidential grouping. In a leading example, one actor failed to repair a car's defective brakes, and another actor then failed to apply the (defective) brakes while driving, thereby injuring the plaintiff. ${ }^{51}$ The exercise of reasonable care by one actor, given the existing unreasonable conduct of the other, would make no dif-

\footnotetext{
${ }^{49}$ Richard W. Wright, Once More into the Bramble Bush: Duty, Causal Contribution, and the Extent of Legal Responsibility, 54 VAND. L. REV. 1071, 1104 (2001); see also supra note 46 (explaining how the duplicated-harm cases satisfy the NESS test).

${ }^{50}$ See David A. Fischer, Insufficient Causes, 94 KY. L.J. 277, 312-17 (2005-2006) (questioning the causal intuitions embodied in the NESS test).

${ }^{51}$ For one of the many invocations of this example, see RESTATEMENT (THIRD) OF TORTS: LiAB. FOR PHYSICAL HARM $\$ 27$ cmt. i (Proposed Final Draft No. 1, 2005).
} 
ference. Applying the defective brakes would not have prevented the injury, nor would the outcome change if the brakes had been fixed and then not applied by the driver. The NESS test does not solve this causal problem. The tortious conduct of one actor is never a necessary element in a set of existing conditions that would be independently sufficient to cause the injury, yet the two actors clearly should incur liability. ${ }^{52}$ The rationale for liability is supplied by evidential grouping, which enables the plaintiff to group the conduct of the two tortious actors for the purpose of proving causation. The combined conduct clearly satisfies the but-for test of causation. The combined tortious conduct is also a necessary element in a set of existing conditions that are independently sufficient to cause the harm, further explaining why the plaintiff can prove causation. As this example illustrates, the NESS test often requires normative judgment regarding the aggregation of causal forces, and a judgment of that type is supplied by evidential grouping. ${ }^{53}$

Evidential grouping accordingly requires some justification for why the plaintiff can prove causation against the group of defendants, thereby disabling a defendant from avoiding liability merely by relying upon the negligence of other defendants. That justification involves the inconsistency that would be produced by this form of exculpatory proof.

The plaintiff's evidence shows that she was injured by the group of defendant tortfeasors, and that each defendant is a member of that group. Unless a defendant rebuts this evidence, she cannot reasonably deny that the plaintiff was harmed by one of the defendants, including herself. The defendant, therefore, cannot avoid liability merely by arguing that the other defendants, more likely than not, caused the harm, if that same argument would enable every other defendant to avoid liability. In these circumstances, the defendant's argument effectively denies that the plaintiff was harmed by any of the defendants, including herself, even though the defendant's failure to rebut the plaintiff's proof disables the defendant from denying liability on this basis. To avoid this inconsistency, the defendant can only rely upon proof rebutting the plaintiff's evidence. Since the plaintiff's evidence

${ }^{52}$ See Fischer, supra note 50, at 301-12 (analyzing this limitation of the NESS test in the context of successive omission cases).

${ }^{53}$ See id. at 288-89 (explaining why the NESS test involves a normative judgment about which forces to aggregate in constructing sufficient causal sets); see also infra notes 131-37 and accompanying text (explaining why the asbestos cases require evidential grouping in order to satisfy the principle of causation). 
shows that no single defendant, more likely than not, caused the harm, a defendant does not rebut the plaintiff's proof merely by arguing that she is not the probable cause of the harm. A defendant must instead prove that she did not act tortiously or could not possibly have caused the injury, the only evidence directly rebutting the plaintiff's proof. $^{54}$

Moreover, when every defendant attempts to avoid liability by relying upon the negligence of other defendants, they are resorting to "naked statistics" rather than particularistic proof, but "[j] udges generally have refused to accept naked statistics or ex ante causal probabilities as evidence of what actually happened on a particular occasion." ${ }^{55}$ The fact that the remaining group of defendants probably

${ }^{54}$ Professors Ripstein and Zipursky make a similar argument about market-share liability. See Ripstein \& Zipursky, supra note 38, at 235 (arguing that the California Supreme Court in Sindell effectively "estopped" the defendants from an argument that would both "concede and deny their liability to each plaintiff"). Ripstein and Zipursky explain that their account of market-share liability "can be understood as ensuring that defendants' liabilities are (at least roughly) limited by the harm they did." Id. at 237. Their justification for market-share liability accordingly "requires a completed wrong," making it inapplicable to alternative liability. Id. at 240. Unlike the account offered by Ripstein and Zipursky, my argument is that the principle in question justifies evidential grouping, which in turn does not require proof that each defendant completed a wrong by tortiously injuring someone.

${ }^{55}$ Richard W. Wright, Causation, Responsibility, Risk, Probability, Naked Statistics, and Proof: Pruning the Bramble Bush by Clarifying the Concepts, 73 IOWA L. REV. 1001, 1050-51 (1988) (citations omitted). Proof by "naked statistics" apparently is ruled out when particularistic proof was otherwise reasonably available. As Judge Posner has explained:

Suppose ... that a person is hit by a bus, and it is known that 51 percent of the buses on the road where he was hit are owned by Bus Company $A$ and 49 percent by Bus Company $B$. He sues $A$ and asks for judgment on the basis of this statistic alone; he presents no other evidence. If the defendant also presents no evidence, should a jury be permitted to award judgment for the plaintiff? The law answers "no." But this is not because of doubt about the evidentiary value of statistical evidence. The true source of disquiet in the example, we believe, is the tacit assumption that the statistic concerning the ownership of the buses is the only evidence the plaintiff can obtain. If it is his only evidence, the inference to be drawn is not that there is a 51 percent probability that it was a bus owned by $A$ that hit him but that he either investigated and discovered that it was actually a bus owned by $B$ (which might be judgment-proof and so not worth suing), or that he has simply not bothered to conduct an investigation. In either event he should lose, in the first case obviously and in the second because a court should not be required to expend any of its scarce resources of time and effort on a case until the plaintiff has conducted a sufficient search to indicate that an expenditure of public resources is reasonably likely to yield a social benefit.

U.S. v. Veysey, 334 F.3d 600, 605 (7th Cir. 2003) (Posner, J.) (citations omitted). The plaintiff's statistical proof in this hypothetical also inappropriately assumes that any 
caused the injury does not explain what happened in this particular case, as it implies that no defendant caused the harm, and yet the plaintiff has provided uncontested proof to the contrary.

As one court explained in a related context, such

[q] uantitative probability ... is only the greater chance. It is not proof, nor even probative evidence, of the proposition to be proved. That in one throw of dice there is a quantitative probability, or greater chance, that a less number of spots than sixes will fall uppermost is no evidence whatever that in a given throw such was the actual result. Without something more, the actual result of the throw would still be utterly unknown. The slightest real [particularistic] evidence that sixes did in fact fall uppermost would outweigh all the [naked] probability otherwise. ${ }^{56}$

In the asbestos cases, for example, the plaintiff has provided particularistic evidence showing that each defendant belongs to the group of tortfeasors that caused the harm, whereas each defendant only relies upon "quantitative probability" or "the greater chance" that the other defendants caused the injury. That evidence, however, is not probative of what actually happened on this particular occasion, since the evidence, when relied upon by each defendant, establishes that no one caused the harm, and that outcome is inconsistent with the plaintiff's uncontested particularistic proof that she was, in fact, injured by at least one of the defendants. To avoid liability, a defendant must instead provide evidence rebutting the plaintiff's particularized proof; a defendant asbestos supplier must show that it did not sell a defective product, or that its defective product could not have caused the plaintiff's harm. ${ }^{57}$

bus from either company is equally likely to have tortiously caused the harm. However, if Bus Company $A$ adopted safety procedures that considerably reduced the risk of negligent driving as compared to the procedures employed by Bus Company $B$, then the fact that Company $A$ had fifty-one percent of the buses in town does not establish that it created a fifty-one percent chance of tortiously causing the harm. The relative proportion of buses owned by the two companies-their "market share"- does not translate into a reliable measure of proportional risk, rendering the proof inadmissible. Either interpretation explains why plaintiffs can prove causation of cancer with the "naked statistics" involved in epidemiologic study, as there is no other form of causal proof reasonably available in these cases and the statistics do not depend upon unproven assumptions regarding the risk. See Restatement (ThiRd) Of TORTS: Liab. FOR PHYSICAL HARM $\S 28 \mathrm{cmt}$. c(3) (Proposed Final Draft No. 1, 2005) (identifying circumstances in which plaintiffs can prove causation with epidemiologic evidence in toxic tort cases). For discussion of how this evidentiary requirement applies to the plaintiff's proof of alternative liability, see infra notes 112-19 and accompanying text.

${ }_{57}^{56}$ Day v. Boston \& Me. R.R., 52 A. 771, 774 (Me. 1902).

${ }^{57}$ See, e.g., Rutherford v. Owens-Ill., Inc., 941 P.2d 1203, 1220 (Cal. 1997) (holding that liability requires proof that the plaintiff's exposure to inhalable asbestos fibers 
A defendant can also avoid liability by proving that one (or more) of the other defendants was a but-for cause of the injury, as long as that same form of proof would not absolve all defendants of liability. The plaintiff then gets full recovery from the remaining group of defendants proven to have caused the harm, an outcome consistent with her prima facie case of liability.

Evidential grouping, therefore, is based upon the following principle:

Once the plaintiff has proven by a preponderance of the evidence that (1) each defendant may have tortiously caused the harm, (2) one or more of the defendants did actually cause the harm, and (3) each defendant would be subject to liability for having actually caused or contributed to the harm, then no defendant can avoid liability by relying upon the tortious conduct of the other defendants, when that form of exculpatory causal proof would enable all of the defendants to avoid liability.

To invoke this principle, the plaintiff must satisfy the ordinary burden of proving that each defendant is responsible for a tortious risk that may have actually caused or contributed to the harm. In order for this proof to establish the plaintiff's prima facie case, each defendant must also be subject to liability in the event that her tortious conduct actually caused or contributed to the harm. ${ }^{58}$ With respect to the element of causation, the plaintiff must satisfy the ordinary burden of proof against the group of defendants. More likely than not, the two tortious fires caused the plaintiff's harm, entitling the plaintiff to receive compensation from the two defendant wrongdoers. More likely than not, the asbestos supplied by the group of defendant manufacturers caused the plaintiff's harm, entitling the plaintiff to receive compensation from the group of defendant wrongdoers. Once the plaintiff has satisfied this burden of proof, she has established a prima facie case of liability, enabling courts to shift the burden of disproving causation to each individual defendant.

When defendants are grouped in a principled manner, the liability rule does not suffer from the problems that others have attributed to it, such as the following:

[C] onsider the case in which $C$ poisons $P$ 's tea and $D$ shoots $P$ before $P$ drinks the tea. Assume also that $B$ was climbing Mt. Everest. Clearly, $D$ 's shooting $P$ was a preemptive cause of $P$ 's death, and neither $C$ 's poison-

from the defendant's product was a "substantial factor[] increasing the risk of cancer").

${ }^{58}$ See infra note 126 (illustrating the role of this requirement). 
ing the tea nor B's climbing Mt. Everest was a cause. The proposed test, however, would treat all three activities as causes. In the aggregate they were a but-for cause of $P$ 's death, while individually none of them was a but-for cause. ${ }^{59}$

The test proposed here would not treat all three defendants as causes of the harm, because there is no principled reason for doing so. Established tort principles enable $B$ to avoid liability, as she did not owe or breach a duty of care to the plaintiff and, in any case, there is no factual uncertainty regarding her lack of causal connection to the injury. The facts conclusively show that $B$ did not tortiously cause the harm. (Indeed, the plaintiff would be subject to sanction for filing suit against $B$ on these facts.) Similarly, there is no factual uncertainty regarding $C$ 's causal connection to the injury. "No serious controversy exists over the proposition that a tortious act that occurs after harm has already happened cannot be a factual cause of the harm." ${ }^{60}$ The plaintiff was killed before drinking the tea poisoned by $C$, eliminating any possibility that $C$ actually caused the wrongful death. Lacking any causal connection to the plaintiff's harm, the evidence does not justify the inclusion of $C$ within any group of culpable defendants that actually caused the harm. Doing so would violate the fundamental tort requirement of causation. The only remaining defendant, $D$, is subject to liability for having tortiously caused the plaintiff's death under the established tort principle involving the liability of a first tortfeasor for tortiously caused duplicated harms. ${ }^{61}$ The plaintiff gets full recovery from $D$; there is no factual uncertainty creating the type of injustice requiring redress by evidential grouping.

Evidential grouping has been rejected by one court on the ground that the plaintiff must always satisfy the ordinary burden of proving that each defendant caused the injury. ${ }^{62}$ That jurisdiction, however, had previously adopted alternative liability, ${ }^{63}$ rendering invalid this reason for rejecting evidential grouping. Alternative liability has only two plausible evidentiary interpretations: (1) It either absolves the plaintiff from the ordinary burden of proving that each individual defendant caused the physical harm, or (2) it requires the plaintiff to

${ }^{59}$ Wright, supra note 4 , at 1781.

${ }^{60}$ Green, supra note 33, at 680 n.30.

${ }^{61}$ See supra note 44 and accompanying text.

${ }^{62}$ See Menne v. Celotex Corp., 861 F.2d 1453, 1461 (10th Cir. 1988) (applying Nebraska law; mandating that the plaintiff prove that "each liable defendant [was] a butfor and substantial contributor to the indivisible injury").

${ }^{63} I d$. at 1460. 
satisfy the ordinary evidentiary burden with respect to causation against the group of defendants. ${ }^{64}$ By adopting alternative liability, a jurisdiction has accordingly either implicitly adopted evidential grouping or decided that the plaintiff does not always have to satisfy the ordinary burden of proving that each defendant caused the physical harm. In such a jurisdiction, evidential grouping cannot be persuasively rejected on the ground that a plaintiff must always satisfy the ordinary burden of proving that each defendant actually caused the harm.

\section{Evidential Grouping as the Basis for Alternative Liability}

Alternative liability can be interpreted as a rule that relaxes the plaintiff's burden of proof or otherwise provides compensation for mere risk exposure. ${ }^{65}$ These interpretations are problematic, though, because they are inconsistent with other bodies of tort law. As the divided case law on market-share liability shows, courts apparently are unwilling to reduce a plaintiff's burden of proving causation or to allow a plaintiff to recover for mere exposure to tortious risk, conditional upon the occurrence of injury. ${ }^{66}$

When based on evidential grouping, alternative liability neither reduces the plaintiff's burden of proof nor provides compensation for mere risk exposure. Evidential grouping explains why alternative liability can satisfy the requirement of causation that is fundamental to tort law.

This conclusion does not show that alternative liability is based upon evidential grouping, however. Even though evidential grouping makes alternative liability consistent with other bodies of tort law, it is a separate question whether the courts have understood alternative liability in these terms. To serve as the basis for alternative liability, evidential grouping must also persuasively explain how courts have conceptualized alternative liability.

The California Supreme Court did not expressly adopt evidential grouping in Summers $v$. Tice, but its rationale for alternative liability clearly depends upon the principle of evidential grouping. As the court explained in a later case, "[t]he fundamental justification for a Summers-type shift of the burden is that without it all defendants might

\footnotetext{
${ }^{64}$ See supra notes 27-29 and accompanying text.

${ }^{65}$ See supra notes 24-27 and accompanying text.

${ }^{66}$ See supra notes 7-8 and accompanying text.
} 
escape liability and the plaintiff be left 'remediless." ${ }^{\circ 7}$ This statement is overly broad. A plaintiff who is unable to satisfy the burden of proof typically is left without a remedy. Unlike these cases, however, the plaintiff in Summers proved that he was deserving of a remedy. He proved that he was tortiously injured, and that each defendant may have been the actual cause of the harm, in which case that defendant would be liable for the plaintiff's injury. Given this proof, it would be an injustice if the plaintiff were left "remediless" merely because each defendant could argue that he was not the most probable cause of the harm. That result violates the principle of evidential grouping. According to that principle, each defendant cannot avoid liability by relying upon the tortious conduct of other defendants when that form of exculpatory proof would enable all of the defendants to avoid liability, despite the plaintiff's proof that each defendant may have tortiously caused the harm, and at least one of them did. This type of argument was relied upon by each of the defendants in Summers and rejected by the court. The principle of evidential grouping straightforwardly explains why the "fundamental justification" for "a Summerstype shift of the burden is that without it all defendants might escape liability and the plaintiff be left 'remediless.'”

The court's reliance on evidential grouping is more clearly reflected in its description of the evidence: "[W]e believe it is clear that the [trial] court sufficiently found on the issue that defendants were jointly liable and that thus the negligence of both was the cause of the injury or to that legal effect." ${ }^{\prime 68}$

The Summers court relied upon evidential grouping in yet another way:

When we consider the relative position of the parties and the results that would flow if plaintiff was required to pin the injury on one of the defendants only, a requirement that the burden of proof on that subject be shifted to defendants becomes manifest. They are both wrongdoers-both negligent toward plaintiff. They brought about a situation where the negligence of one of them injured the plaintiff, hence it should rest with them each to absolve himself if he can. The injured party has been placed by defendants in the unfair position of pointing to which defendant caused the harm. If one can escape the other may also and plaintiff is remediless. Ordinarily defendants are in a far better position to offer evidence to determine which one caused the injury. This

${ }^{67}$ Rutherford v. Owens-Ill., Inc., 941 P.2d 1203, 1220 (Cal. 1997) (citing Summers v. Tice, 199 P.2d 1, 4 (Cal. 1948)).

${ }^{68}$ Summers, 199 P.2d at 2 (emphasis added). 
reasoning has recently found favor in this Court. In a quite analogous situation this Court held that a patient injured while unconscious on an operating table in a hospital could hold all or any of the persons who had any connection with the operation even though he could not select the particular acts by the particular person which led to his disability. There the Court was considering whether the patient could avail himself of res ipsa loquitur, rather than where the burden of proof lay, yet the effect of the decision is that plaintiff has made out a case when he has produced evidence which gives rise to an inference of negligence which was the proximate cause of the injury. It is up to defendants to explain the cause of the injury. It was there said: "If the doctrine is to continue to serve a useful purpose, we should not forget that 'the particular force and justice of the rule, regarded as a presumption throwing upon the party charged the duty of producing evidence, consists in the circumstance that the chief evidence of the true cause, whether culpable or innocent, is practically accessible to him but inaccessible to the injured person." Similarly in the instant case plaintiff is not able to establish which of defendants caused his injury. ${ }^{69}$

This passage refers to the well-known case, Ybarra $v$. Spangard, ${ }^{70}$ the only California case relied upon by the Summers court to justify affirmatively why the plaintiff had satisfied the burden of proof on causation. The passage suggests that a rationale for alternative liability involves the defendants' better access to evidence. But neither defendant in Summers had better access to the evidence than the plaintiff, and the passage ultimately frames the analogy to Ybarra solely in terms of the plaintiff's inability "to establish which of defendants caused his injury" that was proven to have been tortiously caused by one of them. In order for the two cases to be "quite analogous" in this respect, they must be based upon a grouping principle that redresses an injustice created by the defendants' conduct.

In Summers, the defendants can be grouped for causal purposes because each defendant's tortious conduct may have caused the plaintiff's harm, and one of them did. In Ybarra, the plaintiff could not prove that each defendant had acted negligently. ${ }^{71}$ The Ybarra court, though, expressed a different rationale for why the defendants' conduct made it appropriate to group them for evidentiary purposes: "Plaintiff was rendered unconscious for the purpose of undergoing surgical treatment by the defendants; it is manifestly unreasonable for them to insist that he identify any one of them as the person who did

\footnotetext{
${ }^{69} I d$. at 4 (emphasis added) (citations omitted).

${ }^{70} 154$ P.2d 687 (Cal. 1944) (en banc).

${ }^{71} I d$. at 688 .
} 
the alleged negligent act." ${ }^{72}$ Since the defendants acted together as a group in providing surgical treatment to the plaintiff, and since the nature of their conduct made it impossible for the plaintiff to identify the individual tortfeasor, the defendants' conduct provided a sufficient reason to group them for evidentiary purposes. ${ }^{73}$ The Ybarra justification for grouping the defendants clearly differed from the justification in Summers, but in both cases evidential grouping was required in order to avoid the injustice of barring the deserving plaintiff from recovery solely because the nature of the defendants' conduct made it unreasonably difficult for the plaintiff to identify the actual tortfeasor. In each case, a defendant could avoid liability only by proving that he or she was not a tortfeasor who may have caused the harm; the type of proof showing that the defendant did not belong to the group of culpable tortfeasors. ${ }^{74}$ Evidential grouping explains why the Summers court found Ybarra to be "quite analogous."

This interpretation also explains why alternative liability limits the form of exculpatory causal proof available to the defendants, an explanation otherwise lacking in the Restatement rationales for the rule. ${ }^{75}$ When the causal issue is framed in terms of the group of defendants, a defendant cannot admit that she could have tortiously caused the harm and then exculpate herself solely on the ground that the factual uncertainty means that the remaining group of defendants, more

${ }^{72} I d$. at 690 .

${ }^{73}$ In citing to Ybarra and other cases, one California court expressly described the rule in grouping terms:

A group of [independent] persons and instrumentalities may combine in the performance of a medical procedure culminating in an unexpected, mysterious and disastrous result. With the sources of disaster personified in a group of defendants, the demand for evidence pointing the finger of probability at any one of them is relaxed; all may be called upon to give the jury evidence of care.

Inouye v. Black, 47 Cal. Rptr. 313, 316 (Cal. Dist. Ct. App. 1965) (citations omitted). Cf. Saul Levmore, Gomorrah to Ybarra and More: Overextraction and the Puzzle of Immoderate Group Liability, 81 VA. L. REV. 1561, 1565-75 (1995) (interpreting the group liability in Ybarra as "bending the requirements for vicarious liability" and drawing support for such grouping from products liability cases in which the manufacturer of a finished product incurs liability for a defect in an unidentifiable component part produced by another manufacturer).

${ }^{74}$ Therefore, the liability in Ybarra was not based upon a theory of defendants' concert of action such as conspiracy, as these forms of liability do not enable a defendant to exculpate herself on the ground that another defendant caused the harm. See supra notes 35-37 and accompanying text (describing the rules of co-conspiracy, aiding and abetting, and vicarious liability).

${ }^{75}$ See supra notes 21-25 and accompanying text. 
likely than not, caused the injury. This proof merely shows that the harm was caused by the group of tortfeasors and that the defendant is a member of the group. To avoid liability on causal grounds, a defendant must instead provide evidence excluding herself from the causal group. This reasoning explains why the Restatement (Third) can summarily conclude that:

Defendants would be able to satisfy their burden of production when three or more defendants are subject to alternative liability in one of two ways: a defendant might show why it was not the cause of plaintiff's injury or it might show which one of the other defendants was the cause. ${ }^{76}$

These two forms of proof are the only ones that would exclude the defendant from the causal group.

Once the causal issue is evaluated in group terms, it also becomes apparent why the Restatement (Third) rationale for alternative liabilitythat as between a "culpable" defendant and "innocent" plaintiff, the "risk of error" should be put on the defendant-is applicable only to cases involving multiple defendants and not a single defendant. ${ }^{77}$ Insofar as alternative liability involves the grouping of defendants for causal purposes, it depends upon a principle that is not relevant to cases involving a single defendant.

Alternative liability can rely upon evidential grouping without "generat[ing] further legal issues ... over the criteria for the policy decisions," contrary to the claim of a leading treatise. ${ }^{78}$ Without question, the grouping of defendants for evidentiary purposes requires a normative or policy judgment. The policy judgment in Summers differs from that in Ybarra-the former involves tortious conduct engaged in by all defendants, whereas the latter does not. In Summers and related cases of alternative liability, the judgment has already been made by tort law in analogous contexts, like those involving multiple tortious fires or multiple asbestos suppliers. New policy issues might be created by the type of grouping involved in Ybarra, but that form of grouping is not required for purposes of alternative liability.

To be sure, alternative liability requires a distinctive policy judgment-it makes liable one or more of the defendants who did not ac-

${ }^{76}$ Restatement (THIRD) OF TORTS: LIAB. FOR PHYSICAL HARM $§ 28$ reporters' note cmt.j (Proposed Final Draft No. 1, 2005).

${ }^{77} I d$. cmt. $\mathrm{f}$ (stating that this justification for alternative liability is not based on "consideration of the single-defendant case in which plaintiff can prove tortious conduct but is unable to prove factual causation").

${ }^{78}$ DoBBs, supra note $11, \S 171$, at 417 . 
tually cause the plaintiff's harm. The possibility of such legal error does not violate the tort norm regarding the fair allocation of factual uncertainty, however, insofar as the proof identifies the plaintiff as being deserving of compensation and each of the defendants as being presumptively culpable. The defendants could be deemed culpable by virtue of having exposed the plaintiff to tortious risk, but that conception of the plaintiff's tort right has not been widely adopted by the courts. The defendants, more plausibly, are presumptively culpable by virtue of evidential grouping.

Prior to the adoption of alternative liability, evidential grouping was limited to cases in which each defendant's tortious conduct was either a necessary or sufficient condition for the harm. ${ }^{79}$ In Summers, only one defendant's tortious conduct actually caused the injury, making the other defendant's tortious conduct neither a necessary nor sufficient condition for the occurrence of the harm. Evidential grouping, however, makes each defendant responsible for the way in which his tortious conduct interacted with the tortious conduct of the other defendant. ${ }^{80}$ The two defendants interacted to create impenetrable factual uncertainty regarding the identity of the shooter who actually hit the plaintiff, making the two defendants responsible for the uncertainty. Unable to eliminate the uncertainty, each defendant had to share responsibility for the injury. Each defendant's responsibility for his tortious risk justified his own liability, but the liability itself re-

${ }^{79}$ See supra notes 41-53 and accompanying text.

${ }^{80}$ Underlying this form of liability is a conception of outcome-responsibility that has received the most extensive elaboration from Stephen Perry:

The normative power of this conception of outcome-responsibility resides in the idea that the exercise of a person's positive agency, under circumstances in which a harmful outcome could have been foreseen and avoided, leads us to regard her as the author of the outcome. Others can appropriately say of her, and she can say of herself, that she did it, and this is true even if other factors (some of which might be the acts of other persons) also causally contributed to the harm. The agent acted and caused harm under circumstances in which she had a sufficient degree of control to avoid its occurrence, and for that reason she has a special responsibility for the outcome that other persons do not have. That we view outcome-responsibility as reason-affecting in this way is part of our deepest self-understanding of what it means to be a moral agent capable of both acting in the world and acknowledging responsibility for what one has done.

Stephen R. Perry, Responsibility for Outcomes, Risk, and the Law of Torts, in PHILOSOPHY AND THE LAW OF TORTS, supra note 38, at 72, 92-93 (footnote omitted). If the harm were not foreseeable in Summers, the defendants would have avoided liability on that basis. 
quired much more than just the tortious infliction of risk, conditional upon the occurrence of injury.

Once alternative liability is justified in this way, it becomes evident why the Restatement (Third) can defensibly conclude that the "rationale for shifting the burden of proof to defendants whose tortious conduct exposed the plaintiff to a risk of harm is that, as between two culpable defendants and an innocent plaintiff, it is preferable to put the risk of error on the culpable defendants." ${ }^{, 1}$ The Restatement formulation of alternative liability turns out to be fully persuasive, once conceptualized in terms of evidential grouping.

\section{MARKET-SHARE LIABILITY AND EVIDENTIAL GROUPING}

The doctrine of market-share liability originated in cases involving the unpatented, synthetic drug DES, which manufacturers first marketed for use by pregnant women in $1947 .^{82}$ After millions of pregnant women had taken DES, the Food and Drug Administration banned this use of the drug in 1971. Researchers had found that the drug can cause vaginal cancer and other reproductive-organ anomalies in the offspring of mothers who ingested DES during pregnancy. Throughout the entire period when manufacturers were marketing DES to pregnant women, these risks may have been foreseeable. For decades, medical journals had provided evidence of the drug's hazards, and the manufacturers may also have been able to identify the risks by adequate testing. A warning that did not apprise consumers of any such foreseeable risk would render DES a defective product. ${ }^{83}$ Approximately 300 companies may have produced the drug during this period, although the exact number is uncertain. The market was quite fluid, with manufacturers frequently entering and exiting the market. The drug was truly generic and typically had no meaningful brand identification. Each manufacturer sold DES of identical composition, and pharmacists usually filled prescriptions with whatever brand was on the shelf. The lack of brand identity makes it difficult for the plaintiff to identify the actual product seller under any circum-

\footnotetext{
${ }^{81}$ Restatement (ThiRd) OF TORTS: Liab. FOR PhysicAl HaRm $\S 28 \mathrm{cmt}$. f (Proposed Final Draft No. 1, 2005).

${ }^{82}$ For an insightful and thorough discussion of the DES litigation, see Anita Bernstein, Hymowitz v. Eli Lilly and Co.: Markets of Mothers, in TORTS STORIES 151, 151-78 (Robert L. Rabin \& Stephen D. Sugarman eds., 2003). See also Hymowitz v. Eli Lilly \& Co., 539 N.E.2d 1069 (N.Y. 1989).

${ }^{83}$ See Mark A. Geistfeld, Principles of Products Liability 134-56 (2006) (describing the liability rules governing warning defects).
} 
stances, but the problem is even worse in the DES cases. After the plaintiff's mother purchased and ingested the DES, decades passed before the plaintiff offspring suffered injury; consequently, DES plaintiffs usually cannot identify which particular manufacturer sold the drug that caused his or her injury. The plaintiff can use the manufacturer's market share as a proxy for the probability that it actually caused the plaintiff's harm, but each manufacturer had only a small market share. By relying on market-share data, the plaintiff cannot prove that a particular manufacturer, more likely than not, caused the injury. The causation requirement would appear to bar DES plaintiffs from recovery, thereby immunizing DES manufacturers from liability for the widespread injuries caused by their defective products.

This evidentiary problem is addressed by the rule of alternative liability. Each defendant manufacturer exposed the plaintiff to the same tortious risk by supplying the same defective product in the relevant market, just as each defendant in Summers exposed the plaintiff to the same tortious risk by negligently firing at him. Only one manufacturer was the factual cause of the plaintiff's harm, just as only one shooter in Summers injured the plaintiff. However, the nature of the tortious conduct engaged in by each manufacturer (the sale of a generic, defective product) and the resulting harm (cancer or other injury occurring long after exposure to the defect) have made it unreasonably difficult for the plaintiff to identify which particular manufacturer caused the harm-the same type of evidentiary problem confronted by the plaintiff in Summers.

To establish alternative liability, the plaintiff must join all potential tortfeasors in the lawsuit, as in Summers. ${ }^{84}$ Due to the large number of DES manufacturers, the fluid nature of the market, and the passage of time, this requirement is virtually impossible to satisfy. "[P]laintiffs' inability to join all tortfeasor participants has prompted

${ }^{84}$ See Restatement (ThiRd) OF TORTs: Liab. FOR Physical Harm $\$ 28 \mathrm{cmt} . \mathrm{g}$ (Proposed Final Draft No. 1, 2005) ("Courts have insisted that all persons whose tortious acts exposed the plaintiff to a risk of harm be joined as defendants as a condition for alternative liability."). The joinder requirement further explains why alternative liability is not a rule that compensates the plaintiff for risk rather than injury. If the Summers doctrine involves compensation for risk rather than injury, then the plaintiff could sue only one shooter and show, by a preponderance of the evidence, that this individual defendant created a fifty percent chance of causing injury. The proof would sufficiently establish liability for the risk, conditional upon the occurrence of injury. This outcome is barred by the joinder requirement, providing further support for the conclusion that alternative liability does not involve compensation for risk. 
the dismissal of the alternative liability count of several multiple-party actions involving DES." ${ }^{85}$

But why does the plaintiff have to join all of the potential tortfeasors? As an evidentiary matter, the alternative liability cases like Summers are indistinguishable from the DES cases in which the plaintiff is unable to sue all of the manufacturers. In both cases, the plaintiff was injured by tortious conduct, each of the defendants could have been the actual tortfeasor who would be subject to liability, and the nature of their misconduct has made it unreasonably difficult for the plaintiff to identify the actual tortfeasor. The only difference involves the inability of the DES plaintiff to join all of the potential tortfeasors, but like the other problems faced by the plaintiff, this one was also created by the defendants' conduct. Why should this difference matter?

The joinder requirement is not plausibly attributable to the concern about unfairly reducing the plaintiff's burden of proof. Suppose the plaintiff sues a group of six DES manufacturers, each of which had ten percent of the relevant market, and can prove, by a preponderance of the evidence, that each individual defendant sold a defective product (DES) that could have caused her injury. This evidence does not prove that any individual defendant, more likely than not, was the actual injurer. The evidence does show, however, that the group of DES manufacturers, more likely than not, caused the injury. When considered in relation to the group of defendants, the plaintiff has established causation by a preponderance of the evidence, the amount of evidence ordinarily required by tort law.

This form of causal proof can be justified by the principle of evidential grouping. The evidence shows that each DES manufacturer may have tortiously caused the plaintiff's harm, and would be subject to liability if it actually caused the harm, and that the group of defendants, more likely than not, actually caused the harm. On these facts, the "combined conduct [of the defendants], viewed as a whole, is a but-for cause of the event, and application of the but-for rule to them individually would absolve all of them." ${ }^{\prime 66}$ To avoid this injustice, the liability rule can be formulated in terms of evidential grouping. The only exculpatory evidence for each defendant is based solely upon the likelihood that the remaining defendants caused the injury. Tort law has ruled out this type of exculpatory causal proof in analogous con-

852 DAvid G. OWEN ET AL., MAdDEN \& OWEN ON Products Liability $§ 24: 4$, at 652 (3d ed. 2000).

${ }^{86}$ KeEtON ET AL., supra note $30, \S 41$, at 268. 
texts, and can do so here. ${ }^{87}$ A DES manufacturer cannot avoid liability by "hiding behind" the tortious conduct of other DES manufacturers when doing so would bar a deserving plaintiff from recovery altogether. The manufacturer must instead prove that it was not a member of the group that tortiously caused the plaintiff's harm.

Liability in our hypothetical DES case therefore does not require any reduction in the plaintiff's burden of proof, leaving the problem of excessive liability as the only persuasive reason for requiring the plaintiff to join all potential tortfeasors in the lawsuit. If our hypothetical DES plaintiff could establish alternative liability by joining sixty percent of the market, then the group of manufacturers would be jointly liable for the entirety of the plaintiff's injury. Such liability would result in each of the six defendants incurring liability for onesixth of the plaintiff's injury, whereas each had only ten percent of the market. A defendant would incur excessive liability, then, if its liability should be limited by the ten percent likelihood that it actually caused the plaintiff's injury.

In deciding upon the fair amount of liability, the court must compare the interest of the DES plaintiff who has established a right to receive compensation for the injury from the group of defendants, and the interest of each individual defendant as a member of the group. ${ }^{88}$ The compensatory demands that the plaintiff can fairly place upon each member of the group depend upon that individual defendant's relation to the group. An individual who is responsible for the group's conduct can be held liable for the entire injury caused by the group, as in cases involving a concert of action among the defendants. ${ }^{89}$ But in the DES cases, each individual manufacturer is not responsible for the group's conduct; the sale of DES by one manufacturer does not make it responsible for the sales made by other DES

${ }^{87}$ See supra notes $41-53$ and accompanying text.

88 See Brown v. Superior Court, 751 P.2d 470, 487 (Cal. 1988) (identifying the "goal of achieving a balance between the interests of DES plaintiffs and manufacturers of the drug").

89 See RESTATEMENT (SECOND) OF TORTS $\$ 876$ (1977) (stating that a defendant is "subject to liability if he (a) does a tortious act in concert with the other or pursuant to a common design with him, or (b) knows that the other's conduct constitutes a breach of duty and gives substantial assistance or encouragement to the other so to conduct himself"). Similarly, an individual defendant can be responsible for the group's conduct under the theory of enterprise liability. See Hall v. E.I. Du Pont De Nemours \& Co., 345 F. Supp. 353, 376-78 (E.D.N.Y. 1972) (holding all manufacturers in a specific industry liable when the plaintiff is unable to identify the specific manufacturer that caused the harm, and the industry jointly controlled the risk). 
manufacturers. Consequently, the group is defined exclusively in causal terms-the likelihood that it caused the plaintiff's injury. Each individual defendant is a member of the causal group only by virtue of its responsibility for an independent tortious risk that may have injured the plaintiff. Each defendant's contribution to the total risk of injury created by the group, therefore, defines the extent of its responsibility for the group's conduct. In apportioning damages for the plaintiff's injury, the court can accordingly limit the liability of each defendant to the probability that its tortious conduct actually injured the plaintiff. Under this method of apportionment, the interest of the DES plaintiff who has established a right to receive compensation for the injury from the group of defendants exactly corresponds to the interest of each individual defendant as a member of the causal group.

This reasoning explains why courts insist that alternative liability requires joinder of all the potential tortfeasors. Alternative liability gives the plaintiff one hundred percent compensation for the injury from the defendants. When the joinder requirement has been satisfied, the proportional liability of each defendant adds up to one hundred percent. The imposition of joint liability on the group of all potential tortfeasors lets the plaintiff receive full compensation for the injury without requiring any individual defendant to incur liability in excess of the probability that it actually caused the injury. ${ }^{90}$

We are now in a position to see how the California Supreme Court could defensibly "ground[]" market-share liability "upon an extension of the Summers doctrine" by modifying alternative liability to account for the problem of excessive liability. ${ }^{91}$ The issue is complicated, and the court's reasoning is often not fully developed, but its opinions provide the necessary logic for the argument.

Since the plaintiff could not join all potential tortfeasors as required by alternative liability, the court held that the plaintiff must instead join a "substantial share" of the market in order to establish market-share liability. ${ }^{92}$ Properly applied, this requirement ensures that the group of DES defendants, more likely than not, caused the

\footnotetext{
${ }^{90}$ See infra notes 120-122, and accompanying text (explaining why alternative liability does not require pro rata liability).

${ }^{91}$ See Sindell v. Abbott Labs., 607 P.2d 924, 928, 936-37 (Cal. 1980) (extending the Summers doctrine to allow the plaintiff's action to be tried).

${ }^{92}$ See id. at 937 (holding that "only that a substantial percentage is required," rather than seventy-five to eighty percent of the market). The court subsequently referred to this requirement as involving a "substantial share" of the market. Id.
} 
plaintiff's injury. ${ }^{93}$ Once the plaintiff has satisfied this requirement and all of the other remaining requirements for alternative liability, she has established a right to receive compensation for the injury from the group of defendants. Alternative liability would make the defendants jointly liable for the entire injury, resulting in an unfairly excessive amount of liability for each individual defendant. ${ }^{94}$ Each of the DES defendants in our hypothetical case had only ten percent of the market, and so each should be liable for ten percent of the plaintiff's injury-the amount representing each defendant's responsibility (individual risk creation) for the group's conduct (the total tortious risk imposed on the plaintiff). To "protect... defendants against excessive liability," the court in a later case concluded that market-share liability involves several liability, with the liability of each DES defendant being limited by the probability that it actually caused the plaintiff's injury—an amount defined by its market share. ${ }^{95}$ Each of the DES defendants in our hypothetical case had ten percent of the market, making each severally liable for ten percent of the plaintiff's injury.

Having altered the rule of alternative liability in these two respects, the court could defensibly conclude that market-share liability is "an adaptation of the rule in Summers which will substantially overcome [the] difficulties" faced by a plaintiff who cannot join every potential tortfeasor in the lawsuit. ${ }^{96}$ Market-share liability does not fully overcome this difficulty, since the plaintiff receives compensation for only sixty percent of the injury in our hypothetical case. The plaintiff's recovery is limited by the rule of several liability, which makes the individual manufacturer responsible only for the defective products it actually sold. This limitation of liability is required, according to the

\footnotetext{
${ }^{93}$ Sindell says that the substantial-share requirement "significantly diminishe[s]" the "injustice of shifting the burden of proof to defendants to demonstrate that they could not have made the substance which injured plaintiff." Id. Insofar as the substantial-share requirement means that the plaintiff must satisfy the ordinary burden of proof regarding causation against the group of defendants, then the satisfaction of this requirement makes it fair to shift the burden of proof to the defendants. Cf. Murphy v. E.R. Squibb \& Sons, Inc., 710 P.2d 247, 255 (Cal. 1985) (concluding that the substantial-share requirement is not satisfied by ten percent of the market); Sindell, 607 P.2d at 937 (indicating that the substantial-share requirement is less than seventy-five to eighty percent of the market).

${ }^{94}$ See Brown v. Superior Court, 751 P.2d 470, 487 (Cal. 1988) (describing joint liability as frustrating the "goal of achieving a balance between the interests of DES plaintiffs and manufacturers of the drug").

${ }^{95} I d$. at 486.

${ }^{96}$ Sindell, 607 P.2d at 931.
} 
court, in order to avoid the unfairness that would arise if "one manufacturer would be held responsible for the products of another or for those of all other manufacturers if plaintiff ultimately prevails. ${ }^{97}$ The plaintiff can prove causation by reference to the group of manufacturers, but the extent of each defendant's responsibility for the group's conduct is limited by its contribution to the total risk of injury created by the group-the same outcome achieved by alternative liability.

Unlike California, other jurisdictions have adopted markedly different formulations of market-share liability. ${ }^{98}$ The New York Court of Appeals, for example, adopted a rule of market-share liability that does not let the manufacturer exculpate itself from liability by proving that it did not sell the DES that injured the plaintiff. ${ }^{99}$ The rule of market-share liability in Wisconsin is based upon the national product market because of its "fluid" nature and the fact that each DES manufacturer "contributed to the risk of injury to the public and, consequently, the risk of injury to individual plaintiffs." ${ }^{100}$ Under this rule, the DES plaintiff can recover full damages for the entire injury from a single manufacturer in the national market, although "a defendant could escape liability if it proved by a preponderance of evidence that the DES it produced or marketed could not have reached the plaintiff's mother." 101

The liability rules in New York and Wisconsin cannot be justified by Summers-type evidential grouping. In Summers, evidential grouping depended on the principle that each defendant could not avoid liability by relying upon the tortious conduct of other defendants, when that form of exculpatory proof would enable all of the defendants to avoid liability, contrary to the plaintiff's proof that each defendant may have tortiously caused the harm, and at least one of them did. This principle does not apply when the plaintiff cannot prove that each defendant may have been the actual cause of the harm. Proof that a DES manufacturer's products were only distributed in California does not show that it caused any injuries in New York or Wiscon-

97 Id. at 938 .

${ }^{98}$ For an overview of the varied approaches, see 2 DAVID G. OWEN ET AL., supra note 85 , at $\S 24$.

${ }^{99}$ See Hymowitz v. Eli Lilly \& Co., 539 N.E.2d 1069, 1078 (N.Y. 1989) (adopting a market-share theory using a national market to apportion liability based upon "the amount of risk of injury each defendant created to the public-at-large”).

${ }^{100}$ Collins v. Eli Lilly Co., 342 N.W.2d 37, 48-49 (Wis. 1984) (footnote omitted).

101 Thomas ex rel. Gromling v. Mallett, 701 N.W.2d 523, 550 (Wis. 2005). 
sin. By holding the California manufacturer liable, the rule of marketshare liability in New York does not depend upon the principle that justifies evidential grouping in cases of alternative liability like Summers. By adopting an expansive definition of risk exposure, the Wisconsin rule arguably adheres to evidential grouping, but then violates that principle by subjecting a single defendant manufacturer to liability for the entire harm, an amount in excess of its market share.

The California, New York, and Wisconsin rules are all deemed to be different versions of market-share liability, simply because DES cases have traditionally been associated with that doctrine. Rather than rely upon the label of market-share liability as used by the courts in DES cases, the doctrine must be defined in substantive terms. The doctrine was first articulated by the California Supreme Court, and its liability rule is based upon alternative liability. For this reason, the doctrinal basis of market-share liability is appropriately defined in those terms, even though some jurisdictions have adopted so-called rules of market-share liability in DES cases that do not share the California court's doctrinal rationale.

Rather than rely upon the Summers doctrine, one could try to justify market-share liability in other ways. ${ }^{102}$ A justification derived from

${ }^{102}$ The most common justification defines the tort right as entitling the plaintiff to compensation for the tortious infliction of risk, conditional upon the occurrence of injury, but that justification has not been widely embraced by the courts. See supra notes 4-8 and accompanying text (discussing the viability of risk-based liability). Market-share liability could also be justified if the destruction of a personal injury lawsuit were an actionable harm. In a case similar to Summers, Justice Rand of the Canadian Supreme Court justified alternative liability on the ground that the negligent defendants "violated not only the victim's substantive right to security, but . . . also culpably impaired the latter's remedial right of establishing liability. By confusing his act with environmental conditions, he has, in effect, destroyed the victim's power of proof." Cook v. Lewis, [1951] S.C.R. 830, 832 (Can.). The logic of evidential damages can justify both alternative liability and market-share liability. See PORAT \& STEIn, supra note 31, at 186-87 (describing the applicability of the evidential damage doctrine to cases where the wrongdoer is unidentifiable). This rationale for market-share liability does not persuasively justify the liability rule in California, however, because the California Supreme Court has expressly rejected the claim that the destruction of a personal injury lawsuit is an actionable harm. See Temple Cmty. Hosp. v. Superior Court, 976 P.2d 223, 233 n.4 (Cal. 1999) (concluding that "a cause of action for intentional spoliation of evidence by a third party does not exist”). For different arguments that marketshare liability can satisfy the principle of causation, see generally Ripstein \& Zipursky, supra note 38, at 214-49 (arguing that market-share liability is not an extension of alternative liability, with market-share liability justifiably disabling the defendant from simultaneously conceding that it actually caused harm within the general class of plaintiffs and effectively denying that it caused harm to any particular plaintiff, while "ensuring that defendants' liabilities are (at least roughly) limited by the harm they did"); Wright, supra note 49, at 1118-19 n.163 (justifying market-share liability as a "second- 
the Summers doctrine, however, has the advantage of depending upon the established rule of alternative liability. The widespread acceptance of alternative liability implies that its extension to market-share liability should also be widely acceptable.

\section{FURTHER IMPLICATIONS OF EVIDENTIAL GROUPING}

The doctrine of alternative liability has suffered from the lack of an identifiable rationale. "The opinion in Summers did not spell out the reasons for this extraordinary liability in any precise way, perhaps because the result... seems so clearly right on the facts." ${ }^{103}$ The two defendants acted in the same tortious way at the same time, and although each had a fifty percent chance of actually causing the harm, the imposition of liability only incrementally departed from the rule that a defendant can be liable for having tortiously created a $50.1 \%$ chance of causing the injury suffered by the plaintiff. On these facts, the appropriateness of liability is evident, even if the rationale for liability is not. Without an identifiable rationale, however, the liability in Summers seems to be "extraordinary," making courts understandably reluctant to apply the liability rule in any case not factually similar to Summers.

When the American Law Institute first adopted the rule of alternative liability in 1965, seventeen years had passed since Summers was decided by the California Supreme Court. Nevertheless, the case law continued to adhere closely to the facts of Summers:

The cases thus far decided in which the rule [of alternative liability] has been applied all have been cases in which all of the actors involved have been joined as defendants. All of these cases have involved conduct simultaneous in time, or substantially so, and all of them have involved conduct of substantially the same character, creating substantially the same risk of harm, on the part of each actor. It is possible that cases may arise in which some modification of the rule stated may be necessary because of complications arising from the fact that one of the actors involved is not or cannot be joined as a defendant, or because of the effect of lapse of time, or because of substantial differences in the character of the conduct of the actors or the risks which they have created. Since such cases have not arisen, and the situations which might arise are difficult to forecast, no attempt is made to deal with such problems in this

best" liability rule that makes the defendant responsible for the harms it caused in the aggregate due to the infeasibility of achieving the "first-best" outcome in which liability is based on the harm caused in each individual case).

${ }^{103}$ DoBBS, supra note $11, \S 175$, at 427 . 
[Restatement]. The rule stated [herein] is not intended to preclude possible modification if such situations call for it. ${ }^{104}$

Despite this invitation to extend alternative liability beyond the simple facts of Summers, a "number of courts ... have adopted the rule, or stated, that simultaneous tortious conduct by the defendants is required," ${ }^{105}$ just as in Summers. In another apparent effort to adhere to the facts of Summers, some courts have suggested that alternative liability is limited to cases involving few potential tortfeasors, reasoning that fairness requires a high likelihood that any given defendant actually injured the plaintiff. ${ }^{106}$

A similar problem has occurred with respect to market-share liability. Like Summers, the DES cases involve compelling circumstances for liability, even if the reason for liability is not evident. And like the case law produced by Summers, the absence of a persuasive rationale for market-share liability explains why the courts have largely limited the liability rule to these easy cases. "Outside the DES context, market-share liability has been sparingly adopted. Its application has been largely rejected primarily on the ground that the product in question was not fungible, ${ }^{107}$ as it was in the DES cases.

These limitations of liability are no longer defensible once evidential grouping is applied to alternative liability, and that doctrine is then extended and modified to yield market-share liability. So, too, some otherwise puzzling features of liability rules become understandable when considered in relation to evidential grouping.

\section{A. Simultaneity}

Even though the defendants' conduct in Summers occurred at the same time, simultaneity is not required by evidential grouping. As long as each defendant's tortious conduct may have caused the plaintiff's harm, and application of the but-for causal rule to each individual defendant would absolve all of them from liability in contraven-

104 RESTATEMENT (SECOND) OF TORTS $§ 433 \mathrm{~B} \mathrm{cmt.} \mathrm{h} \mathrm{(1965).}$

${ }^{105}$ Restatement (THIRD) OF TORTS: LIAB. FOR PHYSICAL HARM $\$ 28$ reporters' note cmt.j (Proposed Final Draft No. 1, 2005).

${ }^{106}$ E.g., Hymowitz v. Eli Lilly \& Co., 539 N.E.2d 1069, 1074 (N.Y. 1989) (stating that alternative liability in part depends upon "the notion that where there is a small number of possible wrongdoers, all of whom breached a duty to the plaintiff, the likelihood that any one of them injured the plaintiff is relatively high, so that forcing them to exonerate themselves, or be held liable, is not unfair").

${ }^{107}$ In re Methyl Tertiary Butyl Ether (MTBE) Prods. Liab. Litig., 175 F. Supp. 2d 593, 621 (S.D.N.Y. 2001). 
tion of the plaintiff's proof that someone in the group of defendants tortiously caused the harm, then liability can be based upon evidential grouping. The timing of the defendants' tortious conduct is irrelevant. Evidential grouping therefore explains why the Restatement (Third) can defensibly conclude that "simultaneity is both an unnecessary and unsupportable requirement: in each of the cases invoking it, there were other adequate grounds for rejecting alternative liability; no cogent purpose has been articulated for its retention." ${ }^{108}$ As long as the named defendant's conduct has created tortious risk that satisfies the requirements of evidential grouping, a plaintiff asserting alternative liability should not need to show simultaneity.

\section{B. Number of Defendants}

Some courts have suggested that alternative liability must be limited to a few defendants, as it was in Summers, even though there is no apparent reason "why it is 'fair' to impose joint liability without a preponderance of proof of causation in some cases (small number of defendants) but not in others (large number of defendants) when the character of defendant's conduct and plaintiff's difficulty of proof is the same in either instance." ${ }^{109}$ Alternative liability does not require a small number of defendants when based upon evidential grouping. In a case involving a large number of defendants, many individual defendants will have created only a small risk of injuring the plaintiff. Evidential grouping treats these defendants fairly. The liability of each defendant is limited by its contribution to the total amount of tortious risk created by the group of defendants. ${ }^{110}$ If there is a small likelihood that an individual defendant actually injured the plaintiff, then the liability of that defendant is diminished accordingly, eliminating the problem of unfairly excessive liability. Once again, evidential grouping explains why the Restatement (Third) can defensibly depart from the facts of Summers, this time by recognizing that alternative liability "is applicable when there are two or more actors whose tortious conduct expose another to risk."111

${ }^{108}$ RESTATEMENT (THIRD) OF TORTS: LIAB. FOR PHySICAL HARM $§ 28$ reporters' note cmt. j (Proposed Final Draft No. 1, 2005).

${ }^{109}$ Senn v. Merrell-Dow Pharms., Inc., 751 P.2d 215, 222 (Or. 1988) (en banc).

${ }^{110}$ See infra notes 120-122 and accompanying text (explaining why liability is not pro rata but instead based upon the defendant's contribution to the total tortious risk of injury created by the group).

${ }^{111}$ Restatement (Third) Of Torts: Liab. FOR Physical HaRm $\$ 28 \mathrm{cmt}$ j (Proposed Final Draft No. 1, 2005). 


\section{Proximity}

To recover against a particular defendant under alternative liability, the plaintiff must prove that the defendant's tortious conduct may have caused the injury. In developing this requirement, courts have hewn to the facts of Summers:

Similarly [to Summers], in many alternative-liability cases, a close connection exists between the risk of harm created by the defendant's tortious conduct and the harm suffered by the plaintiff. As that connection becomes more tenuous, even while each defendant remains a possible cause of the plaintiff's harm, courts generally refuse to invoke [alternative liability]. Thus, for example, when a defective product injures a person who cannot identify which of several manufacturers made the specific product, courts refuse to invoke alternative liability against all manufacturers of the product. ${ }^{112}$

If the proximity requirement is not satisfied, the plaintiff's proof is nothing other than a "naked statistic" or mere probability that, under some circumstances, the defendant could have caused the harm, precisely the type of evidence regularly rejected by courts. ${ }^{113}$ Any manufacturer might sell a defective product, but that possibility says nothing about what happened on this particular occasion. The plaintiff must provide more specific proof connecting the defendant's tortious risk to the particular injury-the Restatement (Third) requirement of "sufficiently close connection" $" 114$ in order to establish alternative liability with evidential grouping.

In asbestos cases, for example, the plaintiff must identify the manufacturers of the asbestos products to which she has been exposed. ${ }^{115}$ Unlike "naked statistics," such proof shows that in the particular case, the named manufacturer actually imposed a tortious risk upon the plaintiff that may have caused the injury. By forcing the plaintiff to prove direct exposure to each defendant's tortious risk, a court effectively requires the plaintiff to identify the smallest group of tortfeasors that actually caused the harm. The proximity requirement

112 Id. \$ 28 cmt. i.

113 See supra notes 55-57 and accompanying text (explaining how defendants may not rely on quantitative probabilities to rebut plaintiff's particularistic proof).

114 Restatement (ThiRd) OF TORTs: LiAB. FOR Physical HARM $\$ 28 \mathrm{cmt}$ j (Proposed Final Draft No. 1, 2005).

${ }^{115}$ E.g., Rutherford v. Owens-Ill., Inc., 941 P.2d 1203, 1218 (Cal. 1997) (holding that, for a jury instruction shifting the burden of proof to defendants pursuant to the rationale of alternative liability, "plaintiffs bore the burden of proof on the issue of exposure to the defendant's product”). 
produces a defendant group that mirrors that of Summers in the relevant way.

The smallest group of tortfeasors that the plaintiff must identify depends upon the nature of the defendants' conduct towards the plaintiff. In DES cases, for example, the plaintiff does not have to identify the manufacturer of the specific product to which she has been directly exposed. According to the California Supreme Court, the DES cases do not require proof of direct exposure because "hundreds of producers had made the same drug from an identical formula, practically precluding patients from identifying the makers of the drugs they took." ${ }^{116}$ Given the resulting factual uncertainty, a DES plaintiff cannot reasonably identify a group of tortfeasors any smaller than the DES manufacturers that were in the relevant market at the time of the plaintiff's exposure. The nature of the factual uncertainty created by the defendant's conduct makes it unreasonably difficult for the DES plaintiff to prove direct exposure to a particular manufacturer's product, explaining why the sale of DES in the relevant market constitutes a "sufficiently close connection" between plaintiff's injury and defendant's conduct.

The asbestos cases require the plaintiff to prove direct exposure to each defendant's product, even though these cases also involve severe practical problems of proof:

Apart from the uncertainty of the causation, at a much more concrete level uncertainty frequently exists whether the plaintiff was even exposed to dangerous fibers from a product produced, distributed or installed by a particular defendant. The long latency periods of asbestosrelated cancers mean that memories are often dim and records missing or incomplete regarding the use and distribution of specific products. In some industries, many different asbestos-containing products have been used, often including several similar products at the same time periods and worksites. Not uncommonly, plaintiffs have been unable to prove direct exposure to a given defendant's product. ${ }^{117}$

${ }^{116} I d$. at 1218-19. The actual record is more complex. DES was produced from "substantially the same chemical formula," but manufacturers often sold the drug "in a wide variety of forms," including "pills and capsules [that] came in an assortment of sizes, dosages, shapes, coatings, and colors," and even under "unique brand names." Allen Rostron, Beyond Market-Share Liability: A Theory of Proportional Share Liability for Nonfungible Products, 52 UCLA L. REV. 151, 160 (2004) (citations omitted). As the quotation in text indicates, however, in adopting market-share liability the courts have treated DES as if it were largely generic. See, e.g., Collins v. Eli Lilly \& Co., 342 N.W.2d 37, 44 (Wis. 1984) ("DES was, for the most part, produced in a 'generic' form which did not contain any clearly identifiable shape, color, or markings.").

${ }^{117}$ Rutherford, 941 P.2d at 1218. 
Unlike DES cases, the problem of factual uncertainty in the asbestos cases is not a result of the defendants' conduct. At the time of risk exposure, each asbestos manufacturer was not acting in a practically indistinguishable manner. Each sold markedly different branded products, involving substantially different risk levels. ${ }^{118}$ Decades later, an asbestos plaintiff may face severe practical difficulties in identifying the particular manufacturers of the products to which she has been directly exposed, but this obstacle is not a result of the defendants' conduct towards the plaintiff but rather of stale evidence produced by the passage of time. Ordinarily, stale evidence is a reason for exculpating a defendant from liability, as illustrated by statutes of limitations. ${ }^{119}$ Taken alone, stale evidence does not justify grouping defendants for evidentiary purposes.

The courts, therefore, have defensibly required proof of direct exposure in the asbestos cases, even though they have not required such proof in the DES cases. In both instances, the required forms of proof can be justified by evidential grouping.

\section{Apportionment of Liability and the Joinder Requirement}

Some courts have rejected alternative liability in product cases because of concern that joint and several liability would not fairly limit the liability of each defendant manufacturer to the amount of harm it caused. ${ }^{120}$ This problem is eliminated by evidential grouping. When a manufacturer is subject to liability by virtue of its membership in the causal group, the liability of that manufacturer is appropriately limited by its responsibility as a group member. This responsibility is measured by the likelihood that the manufacturer actually caused the plaintiff's harm. ${ }^{121}$ Pursuant to this approach, each manufacturer does not have to incur equal or pro rata shares of liability. For example, any defendant that incurs more than its proportionate share of liability (based upon the amount of the tortious risk for which it is re-

118 See id. at 1216 (describing reasons why asbestos products have such different toxicities); Menne v. Celotex Corp., 861 F.2d 1453, 1456-58 (10th Cir. 1988) (applying Nebraska law; describing the variety of products sold by defendant manufacturers and illustrating how memory can aid plaintiffs in identifying the manufacturers of the products to which the decedent was exposed).

${ }^{119}$ See DOBBS, supra note $11, \S 216$, at 552 (including the deterioration of evidence as a justification for adjusting statutes of limitations).

${ }^{120}$ See RESTATEMENT (THIRD) OF TORTS: LiAB. FOR PHYSICAL HARM $§ 28$ reporters' note cmt. g (Proposed Final Draft No. 1, 2005) (collecting cases).

121 See supra notes 88-90 and accompanying text. 
sponsible) could get contribution from the defendant(s) that paid too little. That outcome could also be achieved more directly if the court allowed such an allocation of liability pursuant to the form of joint and several liability applicable to cases of alternative liability. For example, each defendant in Summers incurred the same amount of liability only because each one was equally likely to have injured the plaintiff. The facts of Summers, not the doctrine of alternative liability, required pro rata liability. The liability is joint because alternative liability requires the joinder of all defendants; the liability is also several in order to allow for differing allocations of liability that might not otherwise be available under pure joint liability requiring pro rata apportionment. ${ }^{122}$ Applied in this manner, joint and several liability fairly limits the liability of each defendant.

As long as the plaintiff satisfies the burden of proving that the group of defendants, more likely than not, tortiously caused the harm, the plaintiff does not have to join all potential tortfeasors. Any requirement that the plaintiff must join all potential tortfeasors is tantamount to a requirement that the plaintiff prove the prima facie case with certainty. When all potential tortfeasors are joined, there is complete certainty that the group of defendants actually caused the harm. A prima facie case of liability, however, does not require the plaintiff to satisfy an element with certainty. Proof that the group of defendants, more likely than not, caused the harm establishes a prima facie case of liability and identifies the plaintiff as deserving of compensation. ${ }^{123}$ Once the plaintiff has established her prima facie case, evidential grouping justifies shifting the burden to the defendants,

${ }^{122}$ Ordinarily, a defendant that incurs joint and several liability can share liability with other defendants (joint liability) or incur the full amount of liability alone (several liability). On its facts, Summers only involved joint liability because each defendant was before the court. See Summers v. Tice, 199 P.2d 1, 2 (Cal. 1948) (upholding a finding "that defendants were jointly liable"). Due to the joinder requirement, any case of alternative liability must also involve joint liability. Nevertheless, courts have interpreted alternative liability as involving joint and several liability. E.g., Rutherford, 941 P.2d at 1215 (stating that the Summers "court concluded [that] both hunters could be found jointly and severally liable for plaintiff's injuries"). In order for several liability to have any meaning in a case of alternative liability, it must provide the basis for imposing upon each defendant its proportionate share of liability when that amount differs from its pro rata share of liability-the same basis for apportionment provided by several liability in market-share cases. Cf. Brown v. Superior Court, 751 P.2d 470, 48587 (Cal. 1988) (adopting several liability limited to the market share held by each defendant manufacturer in cases of market-share liability).

${ }^{123}$ See supra notes 39-40 and accompanying text (explaining the rationale for the preponderance of the evidence standard). 
who must then disprove causation. Evidential grouping therefore also explains why the Restatement (Third) can defensibly conclude that it "would be reasonable to excuse the plaintiff from th $[\mathrm{e}]$ joinder requirement when an immunity or lack of jurisdiction prevents the joinder., ${ }^{124}$

For a case in which every potential tortfeasor has not been joined, the plaintiff should not be able to get full recovery from the defendants. Full recovery would involve liability for each defendant in excess of its contribution to the total tortious risk of harm created by the group of defendants. When a group of defendants is responsible for having created a seventy-five percent chance of causing the harm, the sum total of each defendant's individual liability should equal seventyfive percent of the total harm. Each defendant should not be subject to joint and several liability, but only to several liability in proportion to the amount of tortious risk for which it is responsible. The liability rule is now one of market-share liability and not alternative liability.

\section{E. Proof of Risk Contribution}

In a case of market-share liability, the liability of each defendant need not depend upon its share of the product market, nor must the case involve a fungible product, as neither of these factors was present in Summers. The plaintiff must prove that each defendant created a tortious risk that is fungible only in the sense that the risk may have actually caused the plaintiff's injury, and would subject the defendant to liability if it did cause the harm. This requirement, however, is fully addressed by the proximity requirement and has nothing to do with fungibility per se. There is no need for an additional requirement that the tortious conduct of each defendant must be fungible or substantially similar. ${ }^{125}$

For example, a plaintiff who contracted AIDS from either a tortfeasor who failed to disclose the condition prior to sexual relations or from defective (contaminated) blood purchased from multiple blood

${ }^{124}$ RESTATEMENT (THIRD) OF TORTS: LiAB. FOR PHYSICAL HARM $\$ 28 \mathrm{cmt}$. g (Proposed Final Draft No. 1, 2005).

${ }^{125}$ For extensive argument that fungibility is not required and a good discussion of other forms of proof, see generally Rostron, supra note 116. Unlike the liability rule under present consideration, Rostron apparently interprets both alternative and market-share liability as forms of proportional or risk-based liability, conditional upon the occurrence of injury, which is the same interpretation of these rules that has been offered by others and rejected by a strong plurality of courts. See supra notes 4-8 and accompanying text. 
suppliers over a period of time, should be able to establish alternative liability against both the sexual partner and the blood suppliers if no individual defendant is a but-for cause of the disease. Each defendant exposed the plaintiff to a tortious risk that may have caused the injury, and one of them actually caused the harm and would be subject to liability for having done so. ${ }^{126}$ The fact that some defendants otherwise engaged in entirely different forms of behavior is irrelevant. Once the other requirements for evidential grouping have been satisfied, each defendant's liability depends only upon the amount of tortious risk for which it is responsible. Liability does not always require market shares, and so a more descriptively apt name for the liability rule might be "risk-adjusted" liability.

In applying this rule, the Restatement (Third) expresses concern about the litigation costs of determining the amount of risk attributable to each defendant and "the existence and accuracy" of such data. ${ }^{127}$ These concerns are alleviated by evidential grouping.

The plaintiff must establish liability by a preponderance of the evidence with respect to the issues of duty and breach. The plaintiff must also prove that the group of defendants, more likely than not, tortiously caused the injury. This proof is sufficient to establish the prima facie case of liability against each of the defendant tortfeasors. These requirements prevent the plaintiff from recovering when the causal evidence does not exist or is not sufficiently reliable. Perhaps defendants should incur a legal responsibility for the factual uncertainty in some of these cases, but any rationale for doing so is not based upon evidential grouping. ${ }^{128}$

Once the plaintiff provides the requisite proof on causation, however, she has established a prima facie case of liability against each of the defendant tortfeasors. Under evidential grouping, the remaining

${ }^{126}$ If the defendant blood suppliers in this example were immune from liability due to a blood-shield statute, the plaintiff would lose. Rather than relying exclusively upon the other defendants' tortious conduct-the only form of exculpatory proof barred by evidential grouping - the blood suppliers instead invoke the blood-shield statute. Once these defendants are removed from the case, the plaintiff can proceed only against the sexual partner, who on these facts did not create more than a fifty percent chance of injuring the plaintiff.

${ }^{127}$ Restatement (THIRD) OF TORTS: LiAB. FOR PHysical HaRm $\S 28 \mathrm{cmt}$. o (Proposed Final Draft No. 1, 2005).

${ }^{128}$ Cf. GEISTFELD, supra note 83, at 186-93 (explaining why strict products liability can entail manufacturer liability for the failure to warn of a factual uncertainty based upon reasonable scientific evidence, such as the possibility that the product might be carcinogenic). 
issue involves the extent of liability for each defendant, an issue of damages that does not generate the evidentiary concerns expressed by the Restatement (Third).

Consider the evidence a court would rely upon to determine damages in a case involving a promising third-year law student who was permanently disabled by the defendant's tortious misconduct, leaving her unable to practice law. As part of the damages award, the plaintiff could collect the future earnings she would lose as a result of the tortious injury. Various types of evidence show how much a law student is likely to earn in the future. But even the best evidence of projected future earnings cannot establish that this particular student, more likely than not, would in fact receive these earnings thirty or forty years from now had she not been permanently disabled. Such certainty is not possible for damage calculations extending far into the future. The more-likely-than-not evidentiary standard would bar many claims for lost future earnings.

Barring the plaintiff from recovery would be unjust, though, because the evidentiary problem was created by the defendant's tortious wrongdoing. Had the defendant's tortious conduct not permanently disabled the student, there would be no need to estimate the student's lost future earnings. Hence it would be "a perversion of fundamental principles of justice" if the uncertainty created by the defendant's tortious misconduct were to bar the plaintiff from recovering damages. ${ }^{129}$ To avoid this injustice, tort law reduces the plaintiff's burden of proof regarding causal questions in the damages phase. The plaintiff is only required to establish the amount of damages with "as much certainty as the nature of the tort and the circumstances permit."

Under evidential grouping, the plaintiff must prove that each defendant, more likely than not, may have been a tortious cause of the injury and would be subject to liability for having caused or contributed to the injury, and that the group of defendants, more likely than not, did cause the injury. Having established a right to compensation with sufficiently reliable evidence, the plaintiff faces a reduced evidentiary burden regarding the exact amount of risk attributable to each defendant. That issue is only relevant for determining the amount of a defendant's liability - a damages question. The proof may be difficult to procure, unavailable or inaccurate, but the same problem rou-

${ }^{129}$ Story Parchment Co. v. Paterson Parchment Paper Co., 282 U.S. 555, 563 (1931).

${ }^{130}$ Restatement (SECOND) OF TORTS $§ 912$ (1979). 
tinely exists in the damages phase of tort cases. As is true in other tort cases, the difficulty of determining the exact amount of damages is not a compelling reason for denying the plaintiff recovery altogether. The plaintiff must instead prove the amount of damages, or the amount of tortious risk created by each defendant, with "as much certainty" as can be reasonably expected in the circumstances of the case. $^{131}$

This approach solves an otherwise puzzling problem of factual uncertainty posed by many asbestos cases. The nature of the problem has been fully depicted by the California Supreme Court:

At the most fundamental level, there is scientific uncertainty regarding the biological mechanisms by which inhalation of certain microscopic fibers of asbestos leads to lung cancer and mesothelioma. Although in some cases medical experts have testified that asbestos-related cancer is the final result of the fibrosis (scarring) process, a general reference on the subject describes the link between fibrosis and carcinogenesis as "a debated issue for which further extensive analysis is needed." An answer to this biological question would be legally relevant, because if each episode of scarring contributes cumulatively to the formation of a tumor or the conditions allowing such formation, each significant exposure by the plaintiff to asbestos fibers would be deemed a cause of the plaintiff's cancer; if, on the other hand, only one fiber or group of fibers actually causes the formation of a tumor, the others would not be legal causes of the plaintiff's injuries. ${ }^{132}$

As the court observes, resolution of the factual uncertainty affects the form of the plaintiff's prima facie case. Suppose the injury was caused by only one significant exposure to asbestos fibers. In this scenario, the plaintiff could rely on alternative liability by suing all potential tortfeasors, a requirement that the plaintiff in the above case was unable to satisfy. ${ }^{133}$ Resolution of the factual uncertainty, however, could show that the injury was caused by cumulative exposures. Each

${ }^{131}$ The English courts have adopted this approach for cases in which the plaintiff cannot identify the actual cause of harm. See Allen v. British Rail Eng'g Ltd., [2001] ICR PIQR 942, 952 (A.C.) ("The court must do the best it can on the evidence to make the apportionment and should not be astute to deny the claimant relief on the basis that he cannot establish with demonstrable accuracy precisely what proportion of his injury is attributable to the defendant's tortious conduct."); Holtby v. Brigham \& Cowan (Hull) Ltd., (2000) 3 All E.R. 421, 429 (A.C.) ("I do not think that these cases should be determined on onus of proof. ... [T] he court only has to do the best it can using its common sense ....").

${ }^{132}$ Rutherford v. Owens-Ill., 941 P.2d 1203, 1218 (Cal. 1997) (citations omitted).

${ }^{133}$ See id. at 1208 n.3 (identifying three additional manufacturers that were not named as defendants). 
defendant would then have significantly contributed to the harm, making each defendant a cause of the entire injury and subjecting each to joint and several liability for the entire injury. ${ }^{134}$ As the court framed the issue, whether the plaintiff could recover at all depended upon resolution of the factual uncertainty, an impossibility given the current state of knowledge.

The court rejected alternative liability and imposed joint and several liability upon the group of defendant asbestos suppliers, thereby resolving the problem of factual uncertainty in the plaintiff's favor:

Plaintiffs cannot be expected to prove the scientifically unknown details of carcinogenesis, or trace the unknowable path of a given asbestos fiber. But the impossibility of such proof does not dictate use of a burden shift [under alternative liability]. Instead, we can bridge this gap in the humanly knowable by holding that plaintiffs may prove causation in asbestos-related cancer cases by demonstrating that the plaintiff's exposure to defendant's asbestos-containing product in reasonable medical probability was a substantial factor in contributing to the aggregate dose of asbestos the plaintiff or decedent inhaled or ingested, and hence to the risk of developing asbestos-related cancer, without the need to demonstrate that fibers from the defendant's particular product were the ones, or among the ones, that actually produced the malignant growth. ${ }^{135}$

The import of this holding is unclear. Does it mean that anytime there are two equally plausible scientific interpretations of the evidence, one allowing recovery and the other denying it, the plaintiff can recover? How would such a rule relate to the ordinary evidentiary standard requiring the plaintiff to prove each element of the prima facie case by a preponderance of the evidence? These problems do not exist if the holding allows the plaintiff to recover merely for the tortious infliction of risk, conditional upon injury. Is the liability rule best interpreted in those terms? These questions are highly significant, as the rule of joint and several liability for asbestos exposure has been widely adopted by the courts. ${ }^{136}$

${ }^{134}$ See, e.g., Ravo v. Rogatnick, 514 N.E.2d 1104, 1106 (N.Y. 1987) (explaining that the defendants in such cases "are considered 'joint tort-feasors' and in legal contemplation, there is a joint enterprise and a mutual agency, such that the act of one is the act of all and liability for all that is done is visited upon each"(citations omitted)).

${ }^{135}$ Rutherford, 941 P.2d at 1219 (citations omitted).

136 See RESTATEMENT (THIRD) OF TORTS: LIAB. FOR PHYSICAL HARM $\$ 27$ reporters' note cmt. g (Proposed Final Draft No. 1, 2005) (collecting cases showing that "[s]ince the first asbestos case in which a plaintiff was successful, courts have allowed plaintiffs to recover from all defendants to whose asbestos products the plaintiff was exposed"). 
When based upon evidential grouping, this liability rule can be squared with existing doctrine. This approach enables the plaintiff to base the prima facie case upon the risk-adjusted variant of marketshare liability. Risk-adjusted liability would not give the plaintiff full recovery; damages would instead be discounted by the probability that the group of defendant asbestos suppliers tortiously caused the harm. Due to this potential basis for liability, the plaintiff is now entitled to some recovery, no matter how the factual uncertainty is resolved. If asbestos-related cancer does in fact require only a single exposure, the plaintiff would get partial recovery (under risk-adjusted liability). If the asbestos-related cancer instead involves cumulative exposure, the plaintiff would get full recovery (under the rule of joint and several liability for concurrent or successive tortfeasors). The factual uncertainty, therefore, only affects the extent of liability or amount of damages that should be incurred by each defendant. In the damages phase of trial, tort law places the problem of factual uncertainty upon the defendants, enabling the plaintiff to prove the extent of liability with evidence that is reasonable given the factual uncertainty inherently involved in the damages calculation. The asbestos plaintiff's causal proof satisfies this requirement; there is a reasonable scientific basis for concluding that cumulative asbestos exposure causes injury, despite the equally plausible basis for concluding otherwise (under the single-exposure theory). By awarding plaintiffs full damages pursuant to the rule of joint and several liability, the courts are resolving a damages issue on the basis of a well-established tort principle.

The problem of factual uncertainty often involves the lack of good evidence regarding the amount of tortious risk attributable to each defendant. As illustrated by the asbestos cases, once the plaintiff has proven the prima facie case with sufficiently reliable evidence, the difficulty of quantifying the causal contribution of each defendant does not provide a persuasive reason for denying the plaintiff recovery altogether.

\section{F. The Plaintiff's Causal Responsibility}

According to the Restatement (Third), in cases of alternative liability "[t] he rationale for shifting the burden of proof to defendants whose tortious conduct exposed the plaintiff to a risk of harm is that, as between two culpable defendants and an innocent plaintiff, it is prefer- 
able to put the risk of error on the culpable defendants." ${ }^{137}$ What if the plaintiff is not "innocent" like the plaintiff in Summers, but was instead contributorily negligent in causing the harm? The Restatement (Third) leaves open the question of whether the rationale for alternative liability still applies, ${ }^{138}$ and a leading treatise casts doubt on the availability of alternative liability in such cases. ${ }^{139}$

To rely upon evidential grouping, the plaintiff must prove, by a preponderance of the evidence, that she is a deserving plaintiff who was tortiously injured by the group of defendants, and that each defendant may have tortiously caused the harm and would be subject to liability for having done so. At the time when Summers was decided, a deserving plaintiff was necessarily innocent, because a contributorily negligent plaintiff was barred from recovery altogether. ${ }^{140}$ With the widespread adoption of comparative fault, a contributorily negligent plaintiff is no longer barred from recovery. ${ }^{141}$ A plaintiff does not have to be "innocent" in order to deserve or be entitled to tort compensation from the defendant wrongdoers. The rationale for evidential grouping is based upon the way in which the proof identifies the plaintiff as deserving of compensation, and so comparative fault enables a contributorily negligent plaintiff to rely upon alternative liability and market-share or risk-adjusted liability. ${ }^{142}$

Comparative fault applies to cases in which the evidence shows that both the plaintiff and at least one of the defendants were each a tortious cause of the entire injury, but the factual uncertainty makes it impossible for the plaintiff to identify the actual tortfeasor within a group of defendants. The injury, in other words, would have been avoided if the plaintiff had exercised reasonable care, or it would have been avoided if every defendant had exercised reasonable care.

137 Id. $\$ 28 \mathrm{cmt} . \mathrm{f}$.

138 Id. cmt. n (taking no position as to whether alternative liability still applies in cases of comparative negligence, due to the lack of case law and the fact that alternative liability developed when plaintiff's own negligence would have barred recovery anyway).

${ }^{139}$ DOBBS, supra note $11, \S 175$, at 429 ("If the plaintiff herself is at fault and may have been a cause of her own harm, the strong moral basis for treating the negligent defendants as causes in fact . . could become quite attenuated.”).

${ }^{140}$ Id. $\$ 199$, at 494.

141 Comparative fault began to be widely adopted in the 1970s. See, e.g., Li v. Yellow Cab Co. of Cal., 532 P.2d 1226, 1242 (Cal. 1975) (noting that, by 1975, twentythree states had already adopted some variant of comparative negligence). "By the 1980s, only four states ... had failed to adopt comparative negligence rules." DOBBS, supra note $11, \S 201$, at 504 .

${ }^{142}$ See discussion supra Part I.B. 
These cases involve harms tortiously caused by both the plaintiff and defendant(s), the type of harm apportioned by standard application of comparative fault principles. ${ }^{143}$

The plaintiff's recovery can also be reduced even if her causal contribution to the injury did not involve contributory negligence. In some cases, either the plaintiff or at least one of the defendants was the exclusive cause of harm, but the factual uncertainty makes it impossible to determine who actually caused the injury. The asbestos cases, for example, have involved workers with lung cancer who could have gotten the disease either from smoking cigarettes or asbestos exposure. ${ }^{144}$ In such cases, the plaintiff may be unable to prove that the group of defendants, more likely than not, tortiously caused the harm. Without such proof, the plaintiff cannot prevail under evidential grouping. But if the plaintiff can prove that the group of defendants, more likely than not, tortiously caused the harm, then the plaintiff's recovery should be reduced by her risk contribution, regardless of whether it involved contributory negligence. The plaintiff's conduct created some risk of actually (and exclusively) causing the harm, thereby reducing the risk (and amount of liability) attributable to each defendant. For injuries that could have been caused solely by the plaintiff's conduct, liability can still be fairly apportioned among the parties.

\section{CONCLUSION}

In a case not involving market-share liability or its doctrinal predecessor, alternative liability, Judge Guido Calabresi made an observation about tort litigation that succinctly summarizes the jurisprudence of these two important forms of tort liability:

In cases that are dramatic and involve "hot" issues, there is a tendency for the parties to describe themselves as raising new issues that are remarkable in their legal context. But in fact, such cases are usually best looked at in the most traditional of ways. Courts must see how these cases fit into old categories before considering whether it is either neces-

${ }^{143}$ See Restatement (ThiRd) OF TORTS: Apportionment OF LiAB. $§ 8$ (2000) (discussing factors for assigning shares of responsibility when two or more actors, including the plaintiff, are legal causes of the same injury).

${ }^{144}$ E.g., Rutherford v. Owens-Ill., Inc., 941 P.2d 1203, 1207-08 (Cal. 1997) (involving a worker with lung cancer who smoked a pack of cigarettes every day for over thirty years and also had been heavily exposed to asbestos-containing products throughout the entire period). 
sary or proper to expand those old categories or to create new ones. And so it is with the case before us.

Alternative liability and market-share liability involve "hot" cases raising the remarkable issue of whether tort compensation is for the exposure to tortious risk or the tortious infliction of injury. Rather than identify traditional rationales for these liability rules, many torts scholars have relied upon the nontraditional justification that the tort right involves protection from risk rather than injury. ${ }^{146}$ This nontraditional justification has not fared well in the courts. The courts do not believe that these forms of liability make it "either necessary or proper to expand... old categories or to create new ones," as Calabresi put it. The courts, however, have not adequately identified the traditional justification for the doctrines. The absence of such a rationale has not curtailed the adoption of alternative liability, probably because the leading case of Summers $v$. Tice seemed "so clearly right on the facts." ${ }^{147}$ The absence of a traditional justification has instead severely limited market-share liability. Unable to see how marketshare liability fits into old categories, a strong plurality of courts have rejected that doctrine for rendering "too great a chasm in the tort-law requirement of factual causation." ${ }^{148}$ Based upon a survey of this case law, the Restatement (Third) concludes that there is no "emerging consensus or trend" concerning market-share liability. ${ }^{149}$ The doctrine has stalled in the courts.

The future of market-share liability may critically depend upon whether it can be "fit into old categories." The courts apparently believe that alternative liability has such a justification, and so it provides the most promising doctrinal basis for market-share liability. In order for either of these liability rules to satisfy the fundamental tort requirement of causation, the plaintiff's causal proof must apply to the group of defendant tortfeasors. Grouping the defendants in this manner can be justified by the established tort principle that exculpatory causal proof does not consist of the claim that "Yes, I may have caused the injury, but the remaining group of defendants, more likely

${ }^{145}$ McCarthy v. Olin Corp., 119 F.3d 148, 161 (2d Cir. 1997) (Calabresi, J., dissenting) (citation omitted).

${ }^{146}$ See supra notes 4-6 and accompanying text (discussing the deterrence and fairness justifications for using a risk-based conception of tort liability).

${ }^{147}$ DOBBS, supra note $11, \S 175$, at 427 .

148 Restatement (Third) OF TORTs: Liab. FOR Physical Harm $\S 28 \mathrm{cmt}$. o (Proposed Final Draft No. 1, 2005).

${ }^{149} I d$. 
than not, caused the harm." As applied to each defendant, this form of proof would deny a plaintiff's recovery, even though the defendant cannot reasonably deny that the plaintiff has proven that someone in the group of defendants, and possibly the defendant herself, caused the injury in a manner that entitles the plaintiff to compensation. To avoid this injustice, tort law bars the defendants from relying upon such exculpatory evidence.

A defendant cannot avoid liability merely by blaming the rest of the causal group when the evidence shows that she belongs to the group. The decision is normative, but it has already been made by tort law. It is an "old category" that provides the doctrinal unity between alternative liability and market-share liability. These liability rules often apply to "hot" cases, but as Calabresi observed, that does not mean they must be justified in a new, remarkable manner. 